WSRC-TR-2002-00243, REV. 0

Key Words: Cesium, Waste processing

Retention: Permanent

\title{
HIGH LEVEL WASTE DEMONSTRATION OF THE CAUSTIC-SIDE SOLVENT EXTRACTION PROCESS WITH OPTIMIZED SOLVENT IN THE 2-CM CENTRIFUGAL CONTACTOR APPARATUS USING TANK 37H/44F SUPERNATE
}

M. A. Norato, S. G. Campbell, M. L. Crowder, M. W. Geeting, G. F. Kessinger, R. A. Pierce, and D. D. Walker

November 1, 2002

Westinghouse Savannah River Company

Savannah River Site

Aiken, SC 29808

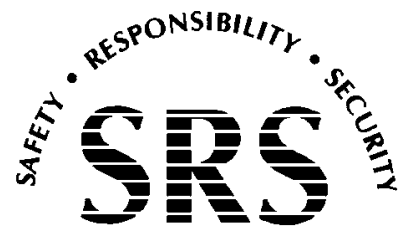

Prepared for the U.S. Department of Energy Under

Contract Number DE-AC09-96SR18500 
This document was prepared in conjunction with work accomplished under Contract No. DE-AC09-96SR18500 with the U. S. Department of Energy.

\section{DISCLAIMER}

This report was prepared as an account of work sponsored by an agency of the United States Government. Neither the United States Government nor any agency thereof, nor any of their employees, makes any warranty, express or implied, or assumes any legal liability or responsibility for the accuracy, completeness, or usefulness of any information, apparatus, product or process disclosed, or represents that its use would not infringe privately owned rights. Reference herein to any specific commercial product, process or service by trade name, trademark, manufacturer, or otherwise does not necessarily constitute or imply its endorsement, recommendation, or favoring by the United States Government or any agency thereof. The views and opinions of authors expressed herein do not necessarily state or reflect those of the United States Government or any agency thereof.

This report has been reproduced directly from the best available copy.

Available for sale to the public, in paper, from: U.S. Department of Commerce, National Technical Information Service, 5285 Port Royal Road, Springfield, VA 22161, phone: (800) 553-6847, fax: (703) 605-6900

email: orders@ntis.fedworld.gov

online ordering: http://www.ntis.gov/help/index.asp

Available electronically at http://www.osti.gov/bridge

Available for a processing fee to U.S. Department of Energy and its contractors, in paper, from: U.S. Department of Energy, Office of Scientific and Technical Information, P.O. Box 62, Oak Ridge, TN 37831-0062,

phone: (865)576-8401,

fax: (865)576-5728

email: $\underline{\text { reports@ adonis.osti.gov }}$ 

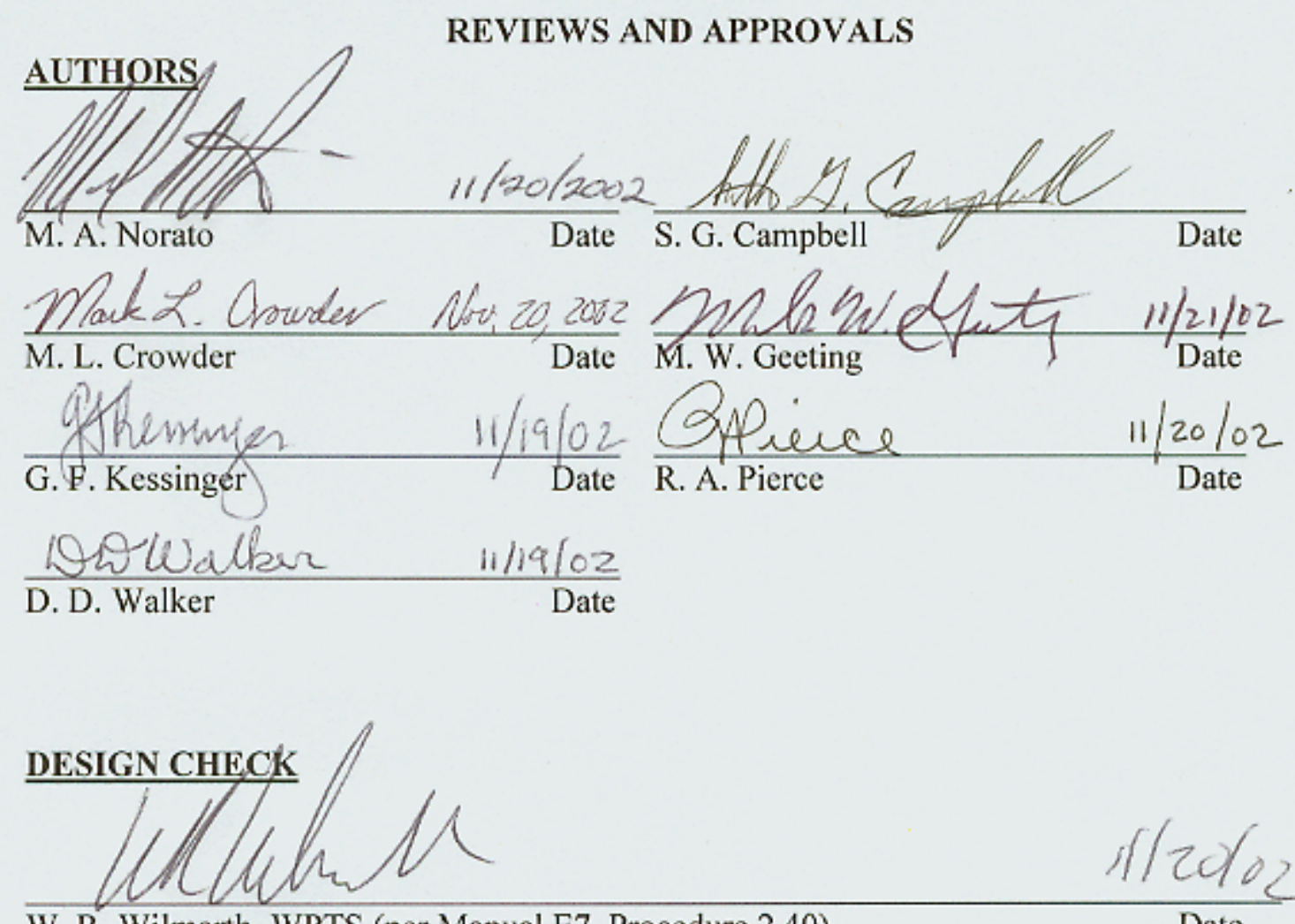

W. R. Wilmarth, WPTS (per Manual E7, Procedure 2.40)

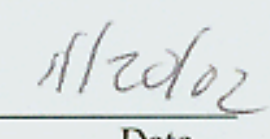

Date

\section{APPROVALS}

Methomberon

M. C. Thompson, TA Solvent Extraction System Lead

I.T. Carter, Direct

J. T. Carter, Director of Engineering, Salt Processing Project

trum D. Nanmon

H. D. Harmon, TEA SPBTechnology Development Manager

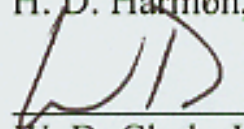

W. D. Clark, Jr., DOE-SR, Technical Support Manager

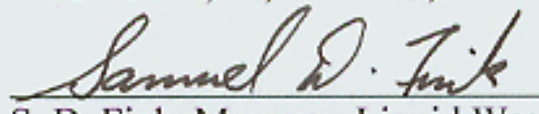

S. D. Fink, Manager, Liquid Waste Processing Group

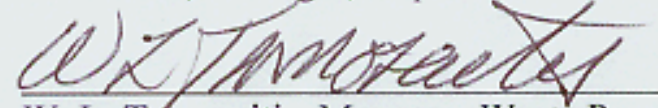

W. L. Tamosaitis, Manager, Waste Processing Technology Section 


\section{TABLE OF CONTENTS}

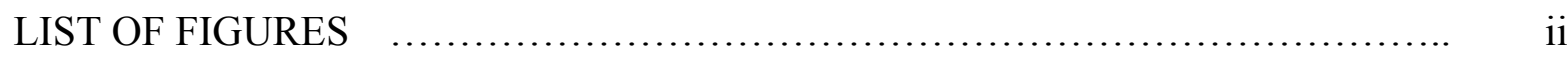

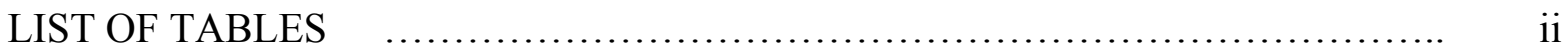

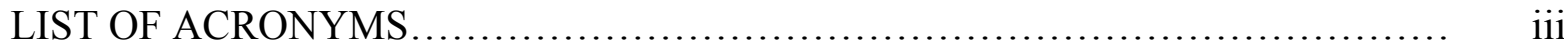

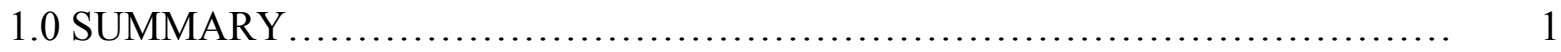

2.0 INTRODUCTION ................................................................. 2

3.0 TANK 37H/44F WASTE TEST REQUIREMENTS ............................ 3

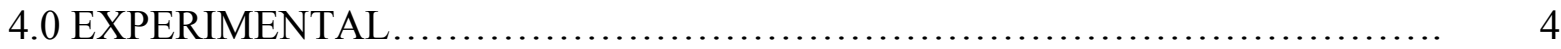

4.1 Tank 37H/44F Simulant...................................................... 4

4.2 Tank 37H/44F Composite Sample Origin \& Preparation....................... 4

4.3 Tank 37H/44F Waste MST Strike and Filtration............................ 5

4.4 Contactor Configuration.................................................. 5

4.4.1 Physical Configuration................................................. 5

4.5 Experimental Operations....................................................... 6

4.6 Sampling and Analysis..................................................... 8

4.6.1 Stage Efficiency .................................................. 9

4.6.2 Decontamination and Concentration Factors............................. 9

4.6.3 Solvent Entrainment and Degradation................................... 9

4.6.4 Minor Components.................................................... 9

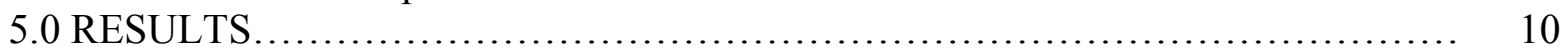

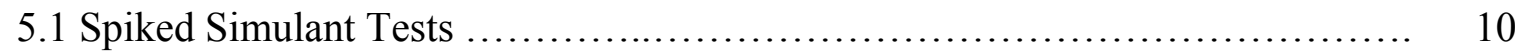

5.1 .1 Hydraulic Performance............................................... 10

5.1.2 Simulant Decontamination.......................................... 12

5.2 Tank 37H/44F Actual Waste Contactor Test.................................. 13

5.2 .1 Hydraulic Performance............................................... 13

5.2 .2 Waste Decontamination.............................................. 14

5.2.3 Solvent Decontamination.............................................. 15

5.2.4 Concentration Factors.............................................. 16

5.2.5 Second Phase Carryover............................................ 17

5.2.6 Solvent Condition and Impurities..................................... 18

5.2.7 Organic Compounds in Aqueous Streams.............................. 18

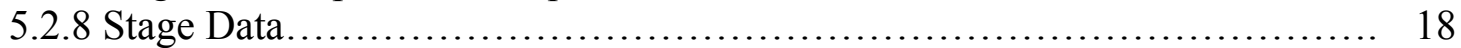

5.2.9 Stage Temperatures.................................................. 21

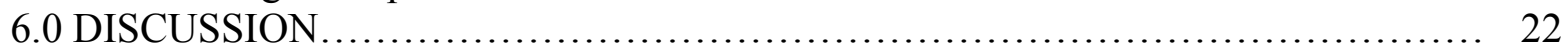

6.1 Tank 37H/44F Waste Composition........................................ 22

6.2 Hydraulic Performance.................................................... 22

6.3 Second Phase Carryover..................................................... 22

6.4 Waste and Solvent Decontamination....................................... 23

6.4.1 Spiked Simulant Testing.............................................. 24

6.4.2 Tank 37H/44FWaste Decontamination................................ 24

6.4.3 Solvent Decontamination........................................... 25

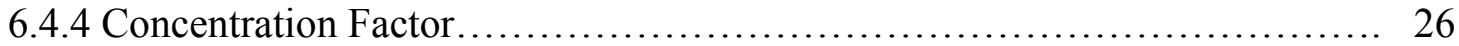

6.5 Solvent Condition and Impurities........................................ 26

6.6 Organic Compounds in Aqueous Streams..................................... 26

Page i of iii. 


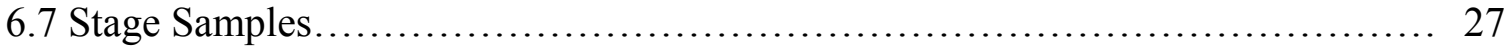

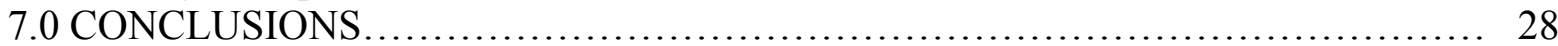

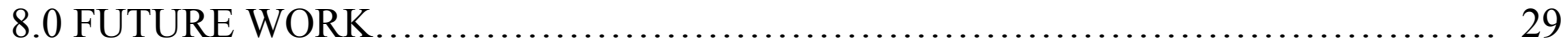

9.0 ACKNOWLEDGEMENTS .................................................... 30

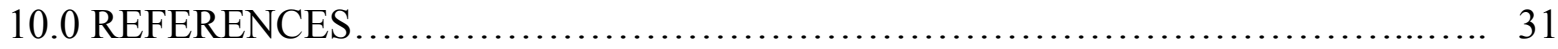

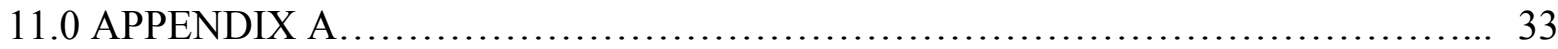

\section{LIST OF FIGURES}

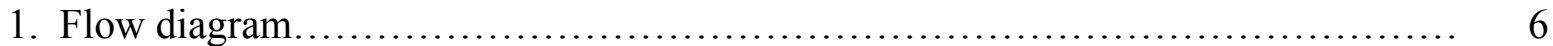

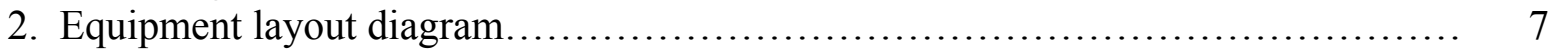

3. General contactor configuration.............................................. 7

4. Spiked simulant decontamination value ..................................... 12

5. Waste DF value as a function of time........................................... 14

6. Solvent DF values as a function of time....................................... 15

7. CF values as a function of time............................................... 16

8. Comparison of stage sample data and SASSE calculations......................... 20

\section{LIST OF TABLES}

I. Origin of Tank 37H/44F composite sample.............................. 4

II. Composition of Tank 37H/44F composite sample.......................... 5

III. Flow setpoints versus flow measured from output

of analytical balances in first spiked simulant tests.......................... 11

IV. Process flow setpoints and observed flow ranges........................... 13

V. Second phase carryover for Tank 37H/44F composite waste test............... 17

VI. Solvent components in aqueous process streams......................... 17

VII. Solvent composition and minor components................................ 18

VIII. Organic compounds in aqueous streams.................................. 19

IX. Stage sample cesium distribution coefficients............................. 19

X. Parameter values used in SASSE calculation.............................. 21

XI. Temperature ranges for contactor sections................................. 21

XII. Combined minor phase carryover results................................ 23

Page ii of iii. 


\section{LIST OF ACRONYMS}

\begin{tabular}{|c|c|}
\hline AA & Atomic Absorption \\
\hline ADS & Analytical Development Section \\
\hline ANL & Argonne National Laboratory \\
\hline BOBCalix & Calix[4]arene-bis-(tert-octylbenzo-crown-6) \\
\hline $\mathrm{BuOH}$ & $n$-butanol \\
\hline $\mathrm{CF}$ & Concentration Factor \\
\hline Cs-7SB & 1-(2,2,3,3-tetrafluoropropoxy)-3-(4-sec-butylphenoxy)-2-propanol \\
\hline CSSX & Caustic-Side Solvent Extraction \\
\hline DBP & dibutyl phosphate \\
\hline DF & Decontamination Factor \\
\hline DOA & di-n-octylamine \\
\hline FMI & Fluid Metering, Inc. \\
\hline GC-MS & Gas Chromatography - Mass Spectrometry \\
\hline HLW & High Level Waste \\
\hline HPLC & High Performance Liquid Chromatography \\
\hline ICP-ES & Inductively Coupled Plasma Emission Spectroscopy \\
\hline ICP-MS & Inductively Coupled Plasma Mass Spectroscopy \\
\hline MST & monosodium titanate \\
\hline $\mathrm{O} / \mathrm{A}$ & organic-to-aqueous volume ratio \\
\hline ORNL & Oak Ridge National Laboratory \\
\hline SASSE & Spreadsheet Algorithm for Stagewise Solvent Extraction \\
\hline SBP & 4-sec-butylphenol \\
\hline SRS & Savannah River Site \\
\hline SRTC & Savannah River Technology Center \\
\hline SVOA & Semivolatile Organic Analysis \\
\hline TMA & trimethylamine \\
\hline TOA & trioctylamine \\
\hline TBP & tributyl phosphate \\
\hline WAC & Waste Acceptance Criterion \\
\hline
\end{tabular}

Page iii of iii. 


\subsection{SUMMARY}

Researchers at the Savannah River Technology Center (SRTC) successfully demonstrated the chemistry of the Caustic-Side Solvent Extraction (CSSX) flow sheet for the decontamination of high level waste using an optimized solvent in a 33-stage, 2-cm centrifugal contactor apparatus. This represents the second CSSX process demonstration using Savannah River Site (SRS) high level waste (HLW). Three tests were performed using radioactively "spiked" simulated Tank 37H/44F composite waste, and a 24-hour demonstration was performed using actual Tank $37 \mathrm{H} / 44 \mathrm{~F}$ composite HLW supernate. Conclusions from this work follow.

- The CSSX process using optimized solvent reduces ${ }^{137} \mathrm{Cs}$ in HLW supernate solutions to concentrations below the Saltstone waste acceptance criterion (WAC) of $45 \mathrm{nCi} / \mathrm{g}$.

- Waste decontamination factors (DFs) as high as 1.37 million resulted during testing.

- The average DF for the waste equaled 520,000 over 24 hours of operation.

- The concentration factor (CF) averaged 12.7 over 24 hours of operation with Tank 37H/44F composite solution.

- Uncertainties in process flow rate measurement and control prevented the test from achieving the target CF of 15.

- Testing occurred over 24 hours of uninterrupted operation, demonstrating hydraulic stability of the contactor array while operating with the optimized solvent formulation.

- Tests with actual Tank 37H/44F composite waste demonstrated extraction and strip section stage efficiencies of $80 \%$.

- These equaled the process goal of $80 \%$ efficiency.

- Carryover of organic solvent in aqueous streams (and aqueous in organic streams) proved less than $1 \%$ when processing Tank $37 \mathrm{H} / 44 \mathrm{~F}$ high level waste.

- Minor components in the high level radioactive waste did not affect the ability of the contactors to efficiently separate the solvent and aqueous phases. 
WSRC-TR-2002-00243, REV. 0

\subsection{INTRODUCTION}

A solvent extraction process for removal of cesium from alkaline solutions has been developed utilizing a novel solvent invented at the Oak Ridge National Laboratory. ${ }^{1-2}$ This solvent consists of a calix[4]arene-crown-6 extractant $\left(\right.$ BOBCalix ${ }^{\circledR}$ ) dissolved in an inert hydrocarbon matrix (Isopar ${ }^{\circledR}$ L). An alkylphenoxy alcohol modifier (1-(2,2,3,3tetrafluoropropoxy)-3-(4-sec-butylphenoxy)-2-propanol, also known as Cs-7SB) added to the solvent enhances the extraction power of the calixarene and prevents the formation of a third phase. An additional additive, trioctylamine (TOA), improves stripping performance and mitigates the effects of any surfactants present in the feed stream. ${ }^{4}$ The solvent extraction process was successfully demonstrated with actual SRS high level waste supernate during testing performed at SRTC in FY-2001. ${ }^{1}$ However, the solvent system has recently been optimized to enhance extractant solubility in the diluent and increase suppressor concentration. The original solvent mixture represented a metastable solution that thermodynamic analysis indicated could experience extractant precipitation during long-term use and storage. Also, radiolytic degradation of the TOA suppressor necessitated an increase in suppressor concentration. Therefore, the concentration of BOBCalix ${ }^{\circledR}$ in the optimized solvent mixture was decreased from $0.01 \mathrm{M}$ in the initial formulation, to $0.007 \mathrm{M}$. The Cs7SB modifier concentration was increased from $0.50 \mathrm{M}$ in the initial formulation, to $0.75 \mathrm{M}$. The TOA suppressor concentration was increased from $0.001 \mathrm{M}$ in the initial formulation, to $0.003 \mathrm{M}$.

The SRS tank farms store soluble high level waste in two forms, supernate and salt cake. Previous testing with actual waste ${ }^{1}$ demonstrated the process chemistry for supernate solution using the original CSSX solvent formulation. However, it was necessary to verify that the new optimized solvent mixture could also effectively decontaminate waste supernate and allow for stable hydraulic operation of the contactor apparatus.

This report summarizes the results of tests at SRTC with radioactively spiked simulated Tank $37 \mathrm{H} / 44 \mathrm{~F}$ waste and actual Tank 37H/44F supernate composite waste. The spiked simulant tests demonstrated that stable hydraulic conditions could be maintained with the new solvent formulation and the radioactive feed could be decontaminated to background levels. The 24 hour actual Tank 37H/44F waste test demonstrated similar hydraulic stability and higher DFs.

Page 2 of 38 


\subsection{TANK 37H/44F WASTE TEST REQUIREMENTS}

The technical and quality assurance plan ${ }^{7}$ defined the requirements for the Tank $37 \mathrm{H} / 44 \mathrm{~F}$ composite waste test in the 2-cm centrifugal contactor apparatus using the optimized solvent formulation. The most important requirements follow.

- Use actual composite high-level radioactive waste supernate solution derived from Tanks $37 \mathrm{H}$ and 44F. The feed solution should be from the same Tank $37 \mathrm{H} / 44 \mathrm{~F}$ composite solution batch used in the FY-2001 demonstration, so as to provide a basis for comparison with previous test results.

- Operate the process for at least 24 hours.

- Determine waste decontamination factor.

- Determine solvent decontamination factor

- Determine cesium concentration factor in strip raffinate.

- Analyze effluent streams for organic compounds, including radiolytic degradation products.

- Compare test results against Saltstone waste acceptance criterion $\left(<45 \mathrm{nCi} / \mathrm{g}{ }^{137} \mathrm{Cs}\right)$. 


\subsection{EXPERIMENTAL}

\subsection{TANK 37H/44F COMPOSITE SIMULANT PREPARATION}

A non-radioactive simulant solution was prepared for use in start up of the test rig, as well for use in the spiked simulant tests. The simulant solution was specified based on chemical analyses of the blended Tank $37 \mathrm{H} / 44 \mathrm{~F}$ waste solution. All batches of simulant solution were prepared to the composition specified in the FY-01 test campaign. ${ }^{1}$

\subsection{TANK 37H/44F COMPOSITE SAMPLE ORIGIN AND PREPARATION}

The optimized solvent demonstration used a composite sample from Tanks $37 \mathrm{H}$ and 44F that remained following previous CSSX testing. ${ }^{1}$ Table I summarizes source information for the sample.

The sodium ion concentration of the waste solution remaining from the previous program exceeded the desired processing concentration of $5.6 \mathrm{M} \mathrm{Na}^{+}$. Personnel transferred a portion of the waste solution to an empty tank and diluted it with $1.6 \mathrm{M} \mathrm{NaOH}$ solution. Dilution produced $69 \mathrm{~L}$ of solution with a sodium ion concentration of $5.52 \mathrm{M}$. Table II lists the composition of the diluted solution. Researchers measured the solution density by weighing portions in 50-mL volumetric flasks using a balance sensitive to $\pm 1 \mathrm{mg}$. Unfiltered portions $(1 \mathrm{~mL})$ were diluted in 99 grams of water or $0.2 \mathrm{M}$ nitric acid and sent to the SRTC Analytical Development Section (ADS) for routine analyses. Exact dilution factors were calculated from the density, weight of the nominal 1-mL sample, and weight of the water, assuming ideal mixing of the waste and water. SRTC ADS personnel measured sodium ion concentrations by inductively-coupled plasma emission spectroscopy (ICP-ES).

TABLE I. Origin of Tank 37H/44F Composite Sample

Source

Date Sampled

Identification Number

Date Received at SRTC

Approximate volume (L)
Tank $37 \mathrm{H}$

$10 / 10 / 2000$

HTF-358

$10 / 12 / 00$

39
Tank 44F

9/27/2000

(no identification)

$9 / 28 / 00$

$32^{*}$

*The sampler contained $38 \mathrm{~L}$. Researchers transferred approximately $6 \mathrm{~L}$ to another program and combined the remaining $32 \mathrm{~L}$ with the Tank $37 \mathrm{H}$ solution. 
WSRC-TR-2002-00243, REV. 0

TABLE II. Composition of the Tank 37H/44F Composite Sample*

\begin{tabular}{lcc}
\cline { 1 - 1 } Component & & Concentration (M) \\
$\mathrm{Ka}^{+}$ & 5.52 \\
$\mathrm{Cs}^{+}$ & & 0.035 \\
& 0.00017 \\
$\mathrm{Free}^{+} \mathrm{OH}^{-}$ & & 4.1 \\
$\mathrm{NO}_{3}{ }^{-}$ & & 0.57 \\
$\mathrm{NO}_{2}{ }^{-}$ & & 0.41 \\
$\mathrm{AlO}_{2}{ }^{-}$ & & 0.18 \\
$\mathrm{SO}_{4}{ }^{2-}$ & & 0.044 \\
$\mathrm{CO}_{3}{ }^{2-}$ & & 0.068 \\
$\mathrm{PO}_{4}{ }^{3-}$ & & 0.006 \\
$\mathrm{~F}^{-}$ & $<0.11$ \\
$\mathrm{Cl}^{-}$ & 0.15 \\
Oxalate & $<0.12$ \\
Formate & $<0.2$ \\
& & \\
pH & & 14 \\
Density & $1.222 \mathrm{~g} / \mathrm{mL}$
\end{tabular}

\begin{tabular}{lcc}
\cline { 1 - 1 } Component & Concentration (mg/L) \\
\cline { 1 - 2 } $\mathrm{Ag}$ & 5.7 \\
$\mathrm{Ba}$ & 1.7 \\
$\mathrm{Ca}$ & 12 \\
$\mathrm{Cd}$ & 1.3 \\
$\mathrm{Cr}$ & 64 \\
$\mathrm{Mo}$ & 78 \\
$\mathrm{~Pb}$ & $<27$ \\
$\mathrm{Sr}$ & $<0.6$
\end{tabular}

* Table shows composition after dilution with $1.6 \mathrm{M} \mathrm{NaOH}$ to achieve $5.52 \mathrm{M} \mathrm{Na}^{+}$.

\subsection{TANK 37H/44F WASTE MST STRIKE AND FILTRATION}

Monosodium titanate (MST) treatment of the diluted Tank 37H/44F composite waste removed strontium and actinides. ${ }^{8}$ The waste contacted the MST for 24 hours prior to filtration. Filtration used a Whatman Polycap ${ }^{\mathrm{TM}} 75 \mathrm{TF}$ filter device $(0.45$ micron Teflon filter element). Personnel stored the filtered solution in a clean carboy for 9 weeks until used in solvent extraction testing.

\subsection{CONTACTOR CONFIGURATION}

\subsubsection{Physical Configuration}

The process equipment consisted of a 33-stage, 2-cm annular centrifugal contactor apparatus used in previous actual waste demonstrations at SRTC. Argonne National Laboratory (ANL) personnel designed and fabricated the contactor stages. A previous ${ }^{1}$ report describes details of the apparatus configuration and process flow sheet. Figure 1 shows a process flow diagram displaying flow conditions specific to this test.

Circulating cooling water maintained the extraction section temperature below $25{ }^{\circ} \mathrm{C}$ in a method similar to that described previously. ${ }^{1}$ In the present study, a manually controlled 


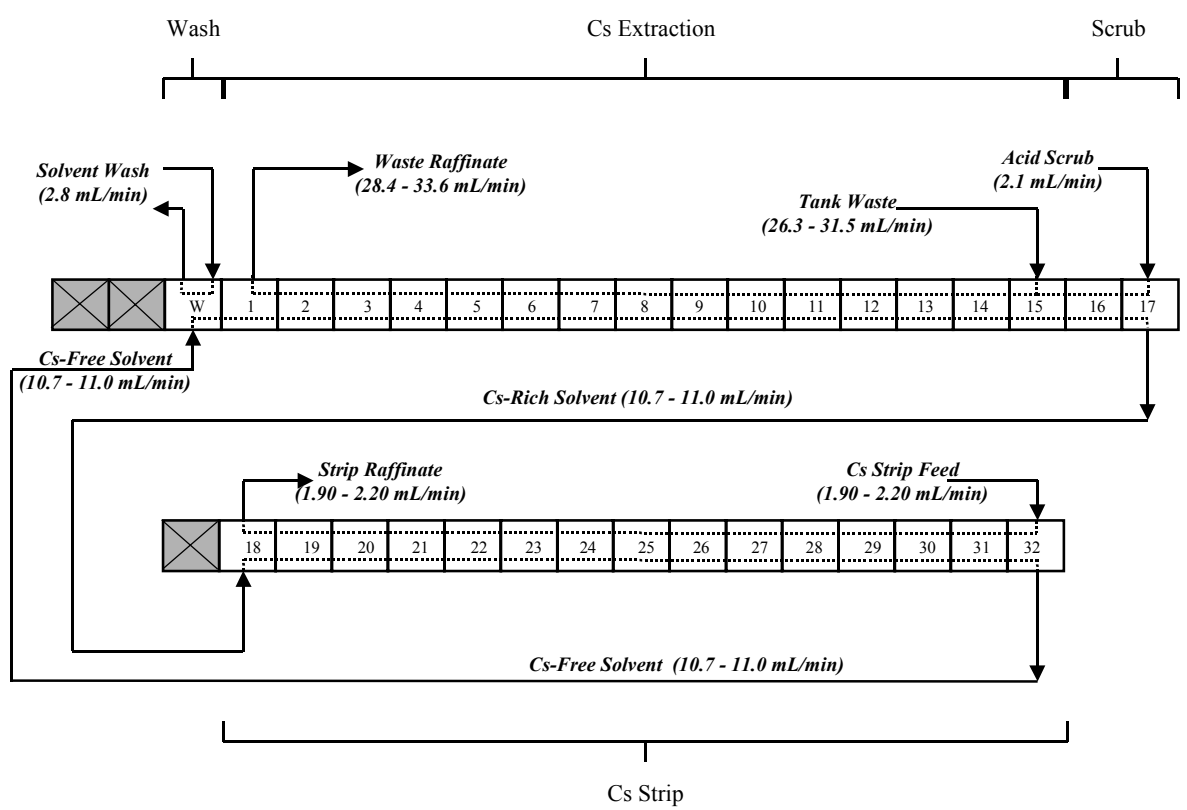

FIGURE 1. Flow Diagram

chiller (NesLab RTE-111) provided cooling water rather than the computer controlled chiller used in earlier testing.

Pumps manufactured by Fluid Metering, Inc. (FMI) fed liquids to the contactors. The pumps were controlled by a computer workstation running the Intellution FIX 7.0 process control software described previously. ${ }^{1}$ As in earlier tests, data were written to the computer hard drive every four hours and manually backed up to a second hard drive every six hours. Archiving to compact disk occurred every 24 hours.

The filtered Tank $37 \mathrm{H} / 44 \mathrm{~F}$ waste was pumped to a $25-\mathrm{L}$ waste feed tank from which it was metered into the contactor apparatus with a Fluid Metering pump. Aqueous-organic decanters fabricated in the SRTC glass shop received the exit streams from the contactors, disengaged the two phases, and allowed measurement of second-phase carryover.

Balances under the waste feed, scrub feed, and strip feed tanks provided an alternative method for measuring process stream flow rates. Figure 2 shows the equipment layout specific to this test and Figure 3 shows the contactor apparatus.

\subsection{EXPERIMENTAL OPERATIONS}

Researchers operated the solvent extraction contactor apparatus following a WPTS operating procedure. ${ }^{9}$ The following summarizes portions of this procedure relating to normal test operation. 


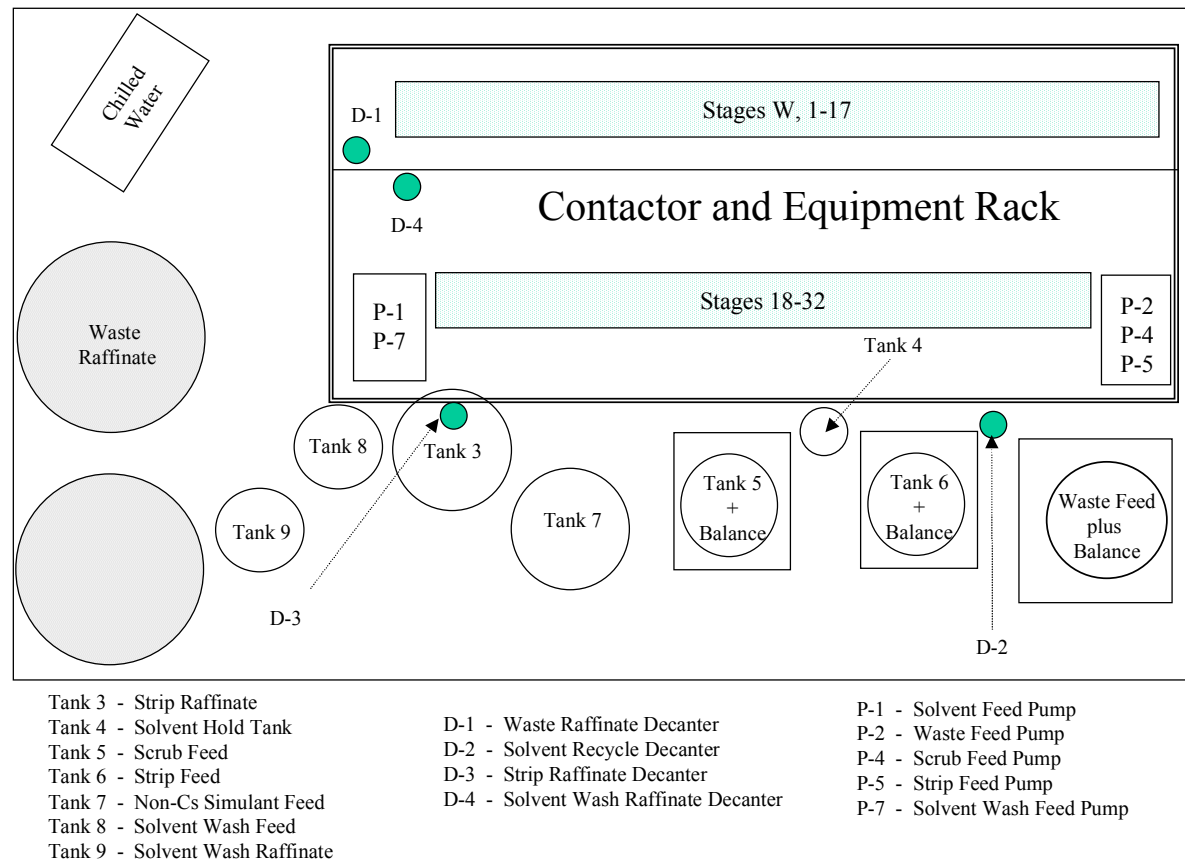

FIGURE 2. Equipment Layout Diagram

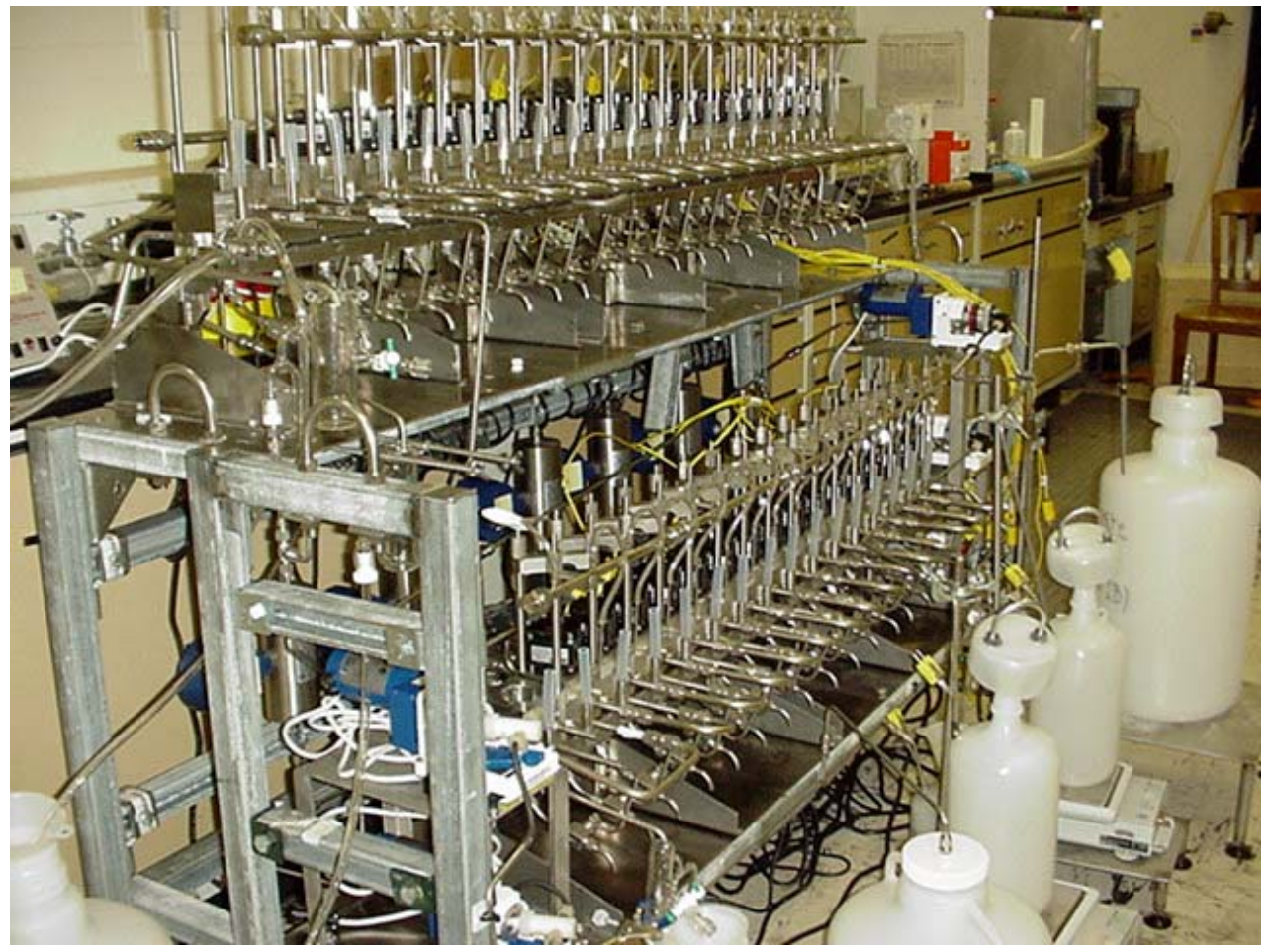

FIGURE 3. General Contactor Configuration. 
The solvent extraction process operates with the aqueous phase continuous. To initiate an experiment, personnel start the contactor rotors with the wash, scrub, and strip stages filled with wash $(0.01 \mathrm{M} \mathrm{NaOH})$, scrub (0.05 $\left.\mathrm{M} \mathrm{HNO}_{3}\right)$, and strip (0.001 $\left.\mathrm{M} \mathrm{HNO}_{3}\right)$ solutions, respectively. With the wash, scrub, and strip feeds running, startup simulant flow initiates in the extraction bank at Stage 15. Startup uses simulated waste solution containing no cesium. After achieving steady aqueous flow through the extraction stages (Stages 1 to 15), the solvent feed to the wash stage begins. When solvent exits the final strip stage (Stage 32) the aqueous feed switches from the cesium-free startup solution to the test solution.

During tests, researchers monitored the test apparatus or calculated the following at the monitoring intervals indicated in parentheses.

- Motor rotation (15 minutes)

- Liquid in standpipes (15 minutes)

- Feed and collection tank levels (30 minutes).

- Decanter levels (1 hour)

- Temperature trends (1 hour)

- Flow rate setpoint trends (1 hour)

- Compared Rheotherm ${ }^{\circledR}$ flowmeter readings and balance flow rates (1 hour).

- Measured process stream flow rates from timed collection volumes (at direction of the technical lead).

- Calculated and compared flow rates from timed collection data and balance data (as directed by the technical lead).

Personnel collected samples by placing sample containers under the outlet points of the continuously-flowing streams. Samples of the solvent feed stream were not taken during the test to avoid disrupting the hydraulic flow conditions.

At the end of each test, researchers stopped the motor rotation and feed pumps simultaneously to minimize disruption of the contents of each stage for the post-test stage samples. Drain valves on each contactor stage allowed removal of each stage's contents at the end of the test.

Equipment flushing followed each test. The extraction stages were flushed with $2 \mathrm{M} \mathrm{NaOH}$ solution to prevent precipitation of aluminum hydroxide in the waste. The strip stages were flushed with strip feed solution $\left(0.001 \mathrm{M} \mathrm{HNO}_{3}\right)$. After flushing with $\mathrm{NaOH}$ or strip feed, all stages were flushed with water.

\subsection{SAMPLING AND ANALYSIS}

Three contactor tests occurred, each with its own objectives and sampling plan. Appendix A provides a copy of the sampling plan developed prior to the test. A Timekeeper Run Sheet containing sample identification, sampling location, and timing was prepared as described in the test procedure ${ }^{9}$. 


\subsubsection{Stage Efficiency}

At the end of the test with Tank $37 \mathrm{H} / 44 \mathrm{~F}$ waste, researchers drained the contents of each stage into polypropylene bottles. Selected samples were transferred to glass separatory funnels, shaken at ambient temperature for 1 minute, then allowed to separate for approximately 16 hours. The final temperature was measured and portions of each phase were analyzed for ${ }^{137} \mathrm{Cs}$. ${ }^{137} \mathrm{Cs}$ concentrations were measured using gamma ray spectroscopic techniques. For low activity samples $\left(<1 \times 10^{7} \mathrm{~d} / \mathrm{m} / \mathrm{mL}\right)$, portions were removed from the shielded facility and counted using routine methods in the SRTC ADS. The ADS method counts $3 \mathrm{~mL}$ of sample for 1000 seconds using an intrinsic germanium solid state detector. For moderate activity aqueous samples $\left(10^{7}\right.$ to $\left.10^{8} \mathrm{~d} / \mathrm{m} / \mathrm{mL}\right)$, aliquots were diluted $\mathrm{x} 10$ or $\mathrm{x} 100$ with water in the shielded cell, and a portion removed for gamma counting. Moderate activity solvent samples were diluted with a solution of 0.5 molar modifier in Isopar ${ }^{\circledR} \mathrm{L}$ solvent. For the high activity samples from the radioactive waste test $\left(>1 \times 10^{8} \mathrm{~d} / \mathrm{m} / \mathrm{mL}\right), 3-$ $\mathrm{mL}$ aliquots were counted using an in-cell, sodium iodide detector. The sodium iodide detector was calibrated with samples that were diluted, removed from the cell, and counted by the ADS.

\subsubsection{Decontamination and Concentration Factors}

During each test, researchers obtained 5- or 10-mL samples of the three process streams (waste raffinate, strip effluent, and stripped solvent) at one-hour intervals. All samples were analyzed by ${ }^{137} \mathrm{Cs}$ gamma counting techniques described above.

\subsubsection{Solvent Entrainment and Degradation}

Researchers estimated the second phase carryover from the volume of solvent that accumulated in the process decanters. Calculations based on the diameter of the decanters and the visually estimated height of the minor-phase layer yielded the volume of the minor phase. Visual estimates of the height of the minor phase are likely accurate to only $\pm 50 \%$. High performance liquid chromatography (HPLC) analysis of periodic samples of each stream provided concentrations of modifier and extractant. Due to the high ${ }^{137} \mathrm{Cs}$ activity in the strip raffinate samples, they were extracted with dichloromethane in the shielded facility and the extract removed for HPLC analysis. Solvent degradation was measured on solvent samples taken at the start and end of the test. Modifier and extractant were measured by HPLC. Trioctylamine was measured by gas chromatography with mass spectral detection (GC-MS).

\subsubsection{Minor Components}

Minor inorganic components in the aqueous streams were measured by ICP-ES, inductively coupled plasma-mass spectrometry (ICP-MS), and atomic absorption (AA) methods. Minor organic components were measured as follows: tri- $n$-butyl phosphate (TBP), trimethylamine (TMA), trioctylamine (TOA), dioctylamine (DOA), 4-sec-butylphenol (SBP), and $n$-butanol $(\mathrm{BuOH})$ were measured by gas chromatography-mass spectrometry; and di- $n$-butyl phosphate by ion chromatography. 
WSRC-TR-2002-00243, REV. 0

\subsection{RESULTS}

\subsection{SPIKED SIMULANT TEST}

\subsubsection{Hydraulic Performance}

Researchers performed a series of three spiked simulant tests prior to the actual waste test. The first was a 12 hour test during which multiple hydraulic upsets were encountered prior to completion. The upsets were caused by slightly bent interstage lines in the strip section and an extraction section rotor (Stage 7) that was binding. The bent interstage lines caused solvent to accumulate in the test rig, flooding the first strip stage (Stage 18), and solvent discharge into the strip raffinate decanter (D-3). The bent interstage lines were identified and bent back to the proper position. The Stage 7 rotor would periodically not start turning without assistance, and it would "spin down" rather quickly upon shut down. This indicates that the rotor was in some way binding in the contactor housing. The rotor was subsequently removed and replaced. Although the first test was completed, decontamination factors were unacceptably low $\left(\sim 10^{3}\right)$, and it was thought that the low DFs were a result of the hydraulic upsets. Therefore, it was decided that the spiked simulant test should be repeated.

The second simulant test consisted of four hours of hydraulic testing with a non-radioactive Tank 37H/44F composite simulant and four hours of operation with the spiked Tank $37 \mathrm{H} / 44 \mathrm{~F}$ simulant. Proper hydraulic operation was achieved in this test, but the DFs obtained from the spiked simulant portion of the test were even lower than in the first test $\left(\sim 10^{2}\right)$. It was later determined that several of the feed solutions, most notably the strip feed were contaminated with high concentrations of cesium. This extraneous contamination caused the solvent not to be decontaminated in the strip section. The continual recycling of contaminated solvent to the system caused the exceptionally low DFs. Sampling and analysis of all process fluids suggested that when the feed tubes were removed from the feed tanks to refill the tanks, the tubes were picking up contamination from inside the cell and depositing it in the feed solutions.

All feed tanks were replaced with clean tanks, and feed tubes were wiped with alcohol wipes whenever they were withdrawn from a feed tank, prior to reinsertion. The test rig was rinsed several times with strip and scrub solutions in an attempt to remove the contamination that was introduced in the previous testing. During test preparation, the rotor on Stage 32 ceased functioning causing strip section flooding. The rotor was subsequently replaced prior to the final simulant test. The third four-hour duration spiked simulant test was performed during which the process operated without interruption.

Hydraulic performance during these simulant tests was somewhat uncertain due to uncharacterized uncertainties in flow measurement and control caused by malfunctioning instrumentation. During the first simulant test, test rig instrumentation was relied upon as the sole source of data for flow measurement and control. However, over the course of that test differences were observed between output from the Rheotherms ${ }^{\circledR}$ and the analytical balances. Table III shows the flow rate setpoints (which correspond to computer control alarm tolerances of Rheotherm ${ }^{\circledR}$ indications) and the flows measured from balance outputs. The 
solvent flow was also measured during the test by timed collection via the recycled solvent sample valve. At a solvent flow setpoint of $9.14 \mathrm{~mL} / \mathrm{min}$, the measured solvent flow was 8.2 $\mathrm{mL} / \mathrm{min}$. The observed flow rates yielded an unacceptably low $\mathrm{O} / \mathrm{A}$ ratio in the extraction section, and low DFs were to be expected.

The second simulant test was performed by operating at the same flow setpoints used in the first test for all fluids except the simulant feed. Since the first test was completed under stable hydraulic conditions and the offset between the setpoints and measured flows were known, the previous setpoints could be repeated and the simulant feed rate could then be reduced to achieve the proper extraction section organic phase-to-aqueous phase (O/A) ratio. When the system again demonstrated stable operation, the flow setpoints were adjusted (assuming the same offsets) to those desired for the spiked simulant test. Although the second test was completed without upset there were observed variations in the reported flows. Periodic measurement of waste raffinate flow was made by timed collection. When compared to the flow rates determined for simulant feed and scrub feed from the balance outputs, the two results were found to differ by almost $3 \mathrm{~mL} / \mathrm{min}$. This continuing variation between flow measurements indicated that the offset between the instrumentation and actual flows was not necessarily constant.

The third spiked simulant test was performed after attempting to address contamination issues in the test rig. The test was performed at the final flow settings used in the second test, and timed waste raffinate and solvent flow measurements were made periodically. Results of the timed collections were used to adjust various flow setpoints as necessary to maintain desired flows. The test ran in a hydraulically stable condition throughout the four-hour run, and was kept running with non-radioactive simulant feed while samples were analyzed. Continuous operation was maintained through the start of radioactive feed in the actual waste test.

TABLE III. Flow Setpoints versus Flow Measured from Output of Analytical Balances in First Spiked Simulant Test.

\begin{tabular}{|c|c|c|}
\hline & $\begin{array}{c}\text { Setpoint } \\
(\mathrm{mL} / \mathrm{min})\end{array}$ & $\begin{array}{c}\text { Measured Flow } \\
(\mathrm{mL} / \mathrm{min})\end{array}$ \\
\hline Waste/Simulant & 42.99 & 38.45 \\
\hline Scrub & 2.84 & 3.53 \\
\hline Strip & 3.09 & 2.34 \\
\hline
\end{tabular}




\subsubsection{Simulant Decontamination}

The combination of residual contamination in the test apparatus and uncertainty in the flow measurement and control led to simulant decontamination factors that were well below the desired value of 40,000 in the first two simulant tests. In the first simulant test, the simulant DF reached a steady state value of approximately 3,000. In the second test, when the sources of external contamination were discovered, the simulant DF only reached a maximum value of 363 .

In the third test, the simulant feed was brought to an average activity of $9.10 \times 10^{7} \mathrm{~d} / \mathrm{m} / \mathrm{mL}$ by adding $500 \mathrm{~mL}$ of Tank $37 \mathrm{H} / 44 \mathrm{~F}$ composite supernate solution to $10 \mathrm{~L}$ of Tank $37 \mathrm{H} / 44 \mathrm{~F}$ simulated waste solution. The simulant DFs were initially 182,000 and decreased to a steady value of approximately 25,000 over the course of the four hour test. The simulant decontamination factor as a function of elapsed time is shown in Figure 4. Although the target DF of 40,000 was not achieved in this test, it is important to note that the activity of the waste raffinate samples in the last two hours of the test was approximately $3 \times 10^{3}$, which was the supposed background contamination level inside the test apparatus. Furthermore, the supernate waste feed in the subsequent actual waste test was anticipated to have an activity that was $1.58 \times 10^{9}$. Decontamination down to the supposed background contamination level would have yielded DFs on the order of $4 \times 10^{5}$. Therefore, the decontamination results of the third spiked simulant test, coupled with stable hydraulic performance and satisfactory concentration factors, were considered sufficient to proceed with the actual waste test.

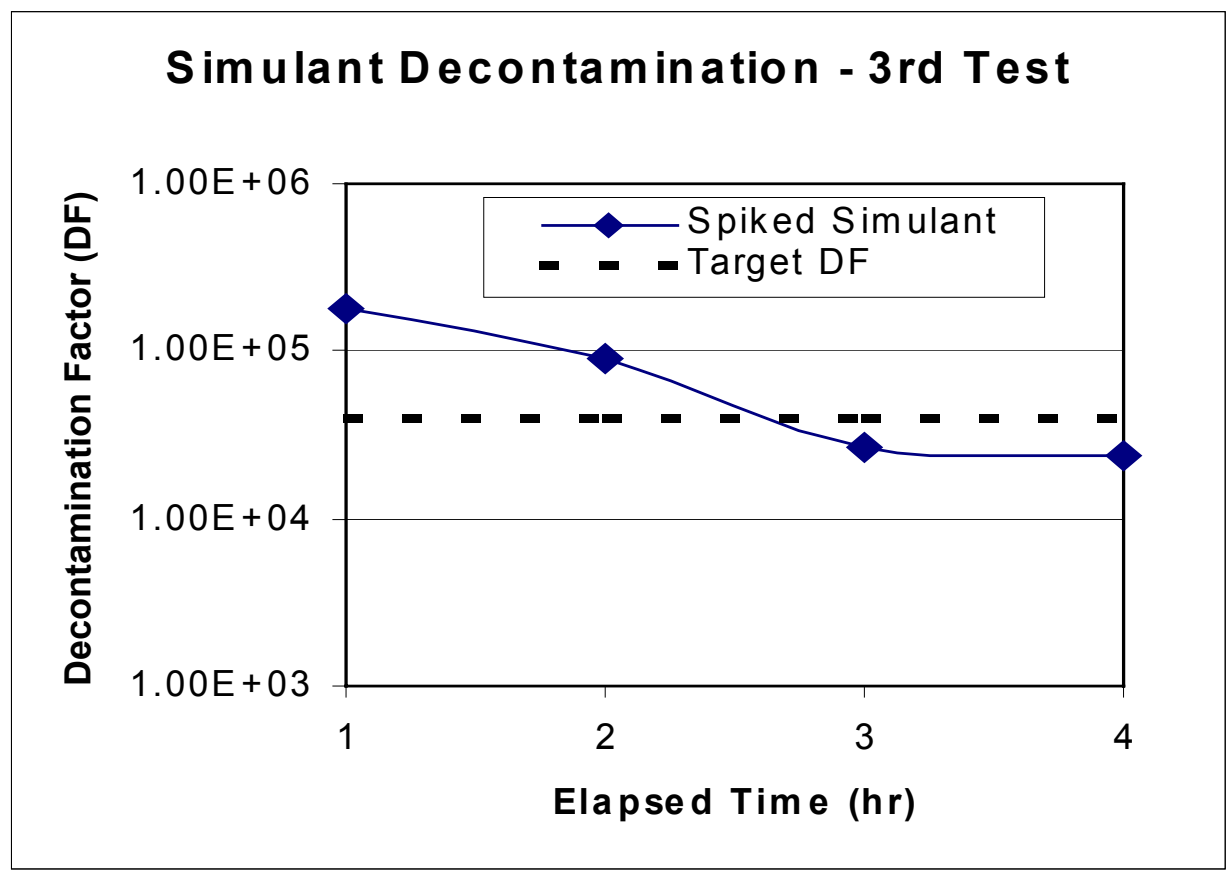

FIGURE 4. Spiked Simulant Decontamination DF Value as a Function of Time. 
WSRC-TR-2002-00243, REV. 0

\subsection{TANK 37H/44F ACTUAL WASTE CONTACTOR TEST}

\subsubsection{Hydraulic Performance}

Researchers processed 45 L of Tank 37H/44F supernate solution in 24 hours of operation. The actual waste demonstration ran for the entire 24-hour period without interruption. Hydraulic performance of the contactor apparatus was excellent with no observations of flooding in any of the stages and no unusual amounts of minor phase accumulation in the decanters.

Although hydraulic operation was stable, flow control was, at times, less accurate than desired for optimal system operation. Flow indications came from the pump motor set points, flowmeter (Rheotherm) measurements, balance measurements, and volumetric flow measurements. Set points and Rheotherm measurements were judged inadequate for precise control based on results from the simulant tests, so balance and volumetric flow measurements were relied on during the actual waste test. Table IV shows the flow set points and observed flow rates for the various process streams.

The waste feed flow rate measured by the balance and volumetrically (corrected for scrub flow) agreed closely. The waste feed rate changed twice during the test. An increase in the waste feed pump set point at 1.5 hours into the test caused the rate to increase by $10 \mathrm{~mL} / \mathrm{min}$. After the set point was lowered at 2.5 hours into the test, the waste feed rate decreased to slightly above its original value.

TABLE IV. Process Flow Setpoints and Observed Flow Ranges.

\begin{tabular}{|c|c|c|c|c|}
\hline $\begin{array}{l}\text { Process } \\
\text { Stream }\end{array}$ & $\begin{array}{l}\text { Duration } \\
\text { (hrs into test) }\end{array}$ & $\begin{array}{l}\text { Flow Setpoint } \\
\text { Range }\end{array}$ & $\begin{array}{l}\text { Flow Rate } \\
\text { (mL/min) }\end{array}$ & Method \\
\hline Waste Feed & $\begin{array}{l}0-1.5 \mathrm{hr} \\
1.5-2.5 \mathrm{hr} \\
2.5-24 \mathrm{hr}\end{array}$ & $\begin{array}{l}38.24 \\
41.03 \\
38.02-42.99\end{array}$ & $\begin{array}{l}27.4 \pm 0.7 \\
37.4 \pm 1.2 \\
29.7 \pm 0.9\end{array}$ & $\begin{array}{l}\text { Balance \& volumetric* } \\
\text { Balance \& volumetric* } \\
\text { Balance \& volumetric* }\end{array}$ \\
\hline Solvent & $0-24 \mathrm{hr}$ & 10.74 & $11.5 \pm 0.7$ & Volumetric \\
\hline Scrub & $0-24$ & 2.04 & $2.3 \pm 0.5$ & Balance \\
\hline Strip & $\begin{array}{l}0-15 \mathrm{hr} \\
15.1 \\
15.1-24\end{array}$ & $\begin{array}{l}2.33 \\
2.33 \\
2.70-2.81\end{array}$ & $\begin{array}{l}2.01 \pm 0.22 \\
1.90 \\
2.15 \pm 0.27 \\
2.08 \pm 0.18\end{array}$ & $\begin{array}{l}\text { Balance \& volumetric } \\
\text { Volumetric } \\
\text { Balance } \\
\text { Volumetric }\end{array}$ \\
\hline
\end{tabular}

*Volumetric measurements were corrected for scrub dilution flow rate of $2.3 \mathrm{~mL} / \mathrm{min}$. 
The solvent feed rate measured volumetrically equaled $11.5 \pm 0.7 \mathrm{~mL} / \mathrm{min}$. No changes occurred in the pump setpoint during the test and no trends in the flowrate were observed.

The scrub feed rate $(2.3 \pm 0.5 \mathrm{~mL} / \mathrm{min})$ was measured by the balance and agreed well with the expected rate $(2.5 \mathrm{~mL} / \mathrm{min})$ based on a pretest set point calibration. No changes to the set point occurred during the test and no trends were observed in the flow rate.

The strip feed rate was measured by balance during the first 15 hours of the test. At 15.1 hours, the first volumetric measurement indicated the flow rate was lower than targeted. The pump set point was increased and volumetric measurements were continued. Strip feed flow rates measured by the balance before and after the set point change do not differ significantly (in a statistical sense) because of the large uncertainty in the measurements. However, the average feed rate values suggest the rate increased by $7-9 \%$. The pump set point was increased a second time at 21.5 hours.

\subsubsection{Waste Decontamination}

The Tank 37H/44F waste decontamination results demonstrate the cesium-removal capacity of the optimized solvent greatly exceeds process requirements. Figure 5 shows a plot of the waste DF values as a function of elapsed time during the test. The DF values display a maximum value of 1.37 million, and vary between 0.4 and 1.0 million with one exception. The single data point outside of this range occurred during the short period of high feed flow at 2 hours into the test. Neglecting the low data point increases the average DF to 630,000. Decontamination results for the entire 24 hours of operation greatly exceed the process target of 40,000, and the specific target of 12,400 to meet the Saltstone waste acceptance criterion for ${ }^{137} \mathrm{Cs}$ of $<45 \mathrm{nCi} / \mathrm{g}$. The calculated average ${ }^{137} \mathrm{Cs}$ concentration in the decontaminated waste was $1.1 \mathrm{nCi} / \mathrm{g}$, or more than an order of magnitude below the Saltstone WAC.

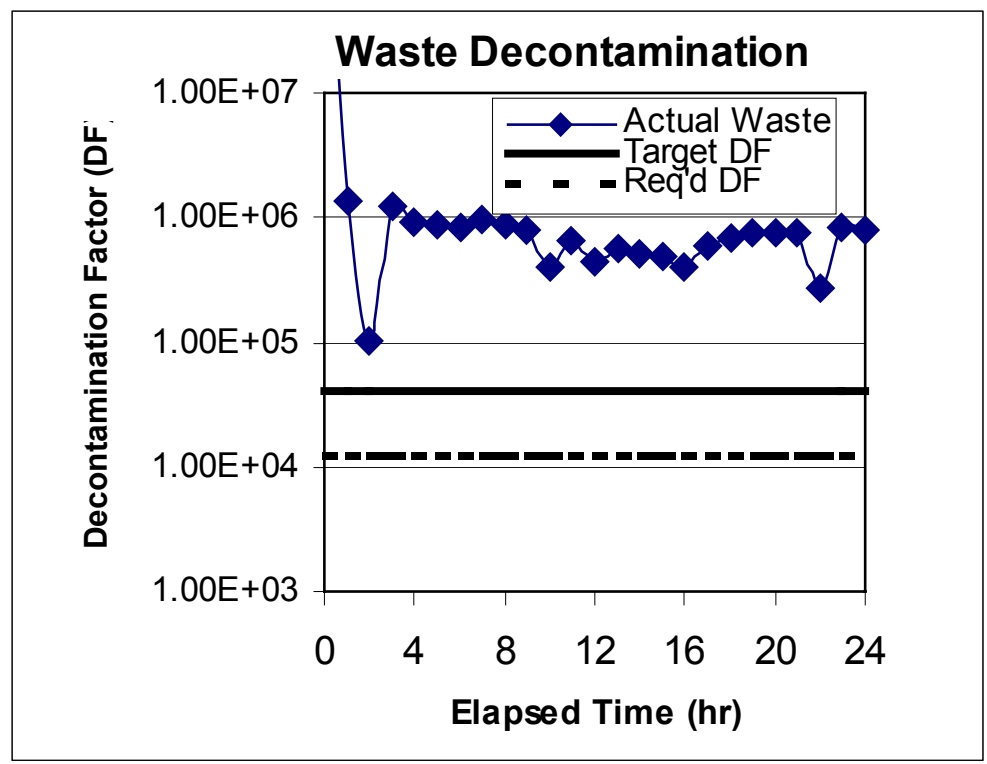

FIGURE 5. Waste DF Value as a Function of Elapsed Time. 
Ignoring the low data point at 2 hours, Figure 5 shows a slow decrease in DF during the first 15 hours of the test. The likely cause of the DF decrease is an increasing amount of cesium in the solvent delivered to the extraction section. This is discussed further in the sections on Solvent Decontamination (Sections 5.2.3 and 6.4.3). The downward trend in DF reversed after the strip feed rate was increased at 15.1 hours into the test. After the increase, the DF performance shows a general recovery to a steady value of just under 1 million until the end of the test.

\subsubsection{Solvent Decontamination}

The solvent decontamination factor calculated for the actual waste demonstration is defined as follows.

$$
\text { Solvent DF }=\frac{\left({ }^{137} \text { Cs Activity in the Waste Feed }\right)}{\left({ }^{137} \text { Cs Activity in the Stripped Solvent }\right)}
$$

The solvent DF attained a maximum value of 470,000, a minimum value of 39,200, and averaged 99,800 over the 24-hour test period. Figure 6 shows a plot of the solvent DF as a function of time during the test. The solvent DF declined steadily during the first 15 hours of the test. Following the change in the strip feed pump set point at 15.1 hours, the solvent DF steadily recovered and equaled its initial value by the end of the test.

Strip feed flow rates measured by the balance before and after the set point change do not differ significantly (in a statistical sense) because of the large uncertainty in the measurements. However, the average feed rate values suggest the rate increased by $7-9 \%$ (Table IV).

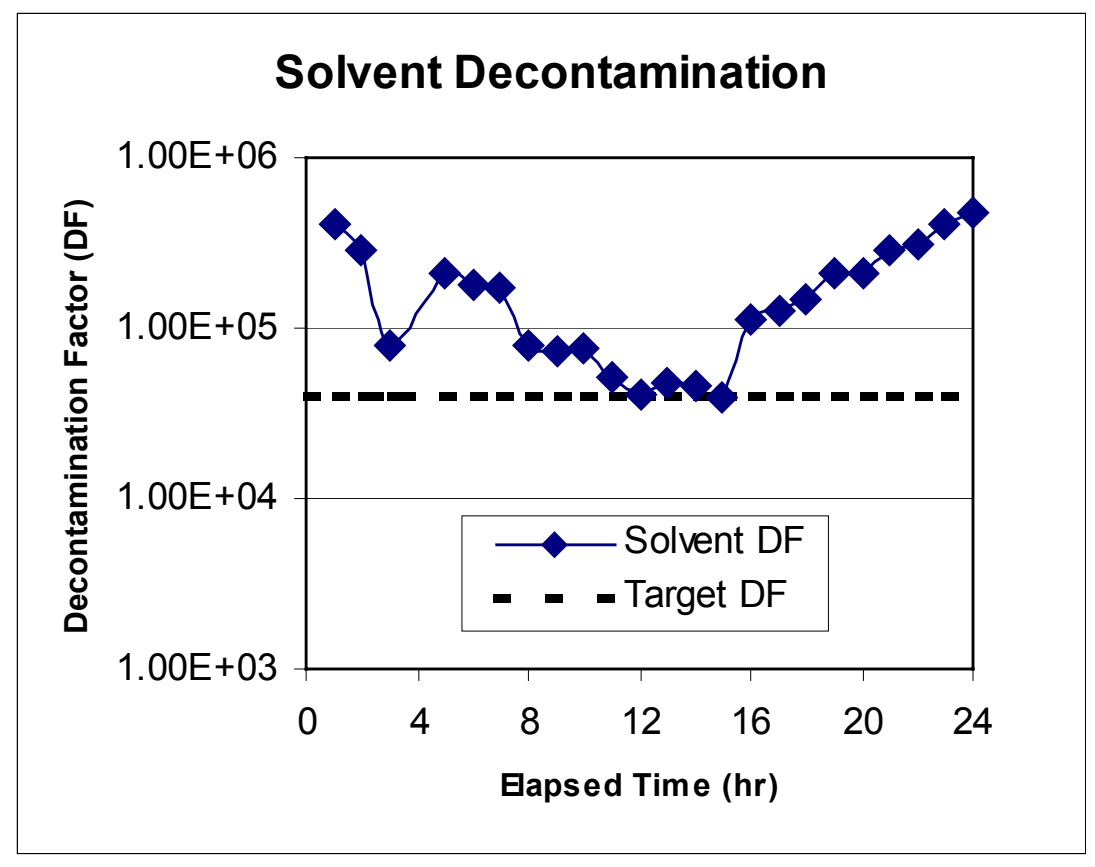

FIGURE 6. Solvent DF Values as a Function of Elapsed Time. 


\subsubsection{Concentration Factors}

The concentration factor is defined by the following equation.

$$
\mathrm{CF}=\frac{\left({ }^{137} \mathrm{Cs} \text { concentration in strip raffinate }\right)}{\left({ }^{137} \mathrm{Cs} \text { concentration in waste feed }\right)}
$$

The CF values measured for the actual waste demonstration indicate steady state was achieved within the first two hours after the test began. The average CF value in this phase of testing was approximately $12.7 \pm 0.6$. Figure 7 shows a plot of the $\mathrm{CF}$ values as a function of time during the test. There was considerable oscillation of the $\mathrm{CF}$ values about the average. The $\mathrm{CF}$ averaged somewhat lower than the process target value of 15 and the expected value of $14.8 \pm 1.7$ calculated from the average waste feed and strip feed flow rates (Table IV). The low value and the discrepancy between it and the expected value are likely due to a systematic error (bias) in one or more of the feed rate measurements. Prior to any future testing with the $2-\mathrm{cm}$ contactor apparatus, improved methods for monitoring and controlling feed rates are advisable.

The change in strip feed rate at 15.1 hours $(7-9 \%)$ should cause a corresponding change in the CF. Since the magnitude of this change approximately equals the standard deviation in the measurements, it is not surprising that the change is not apparent in Figure 6.

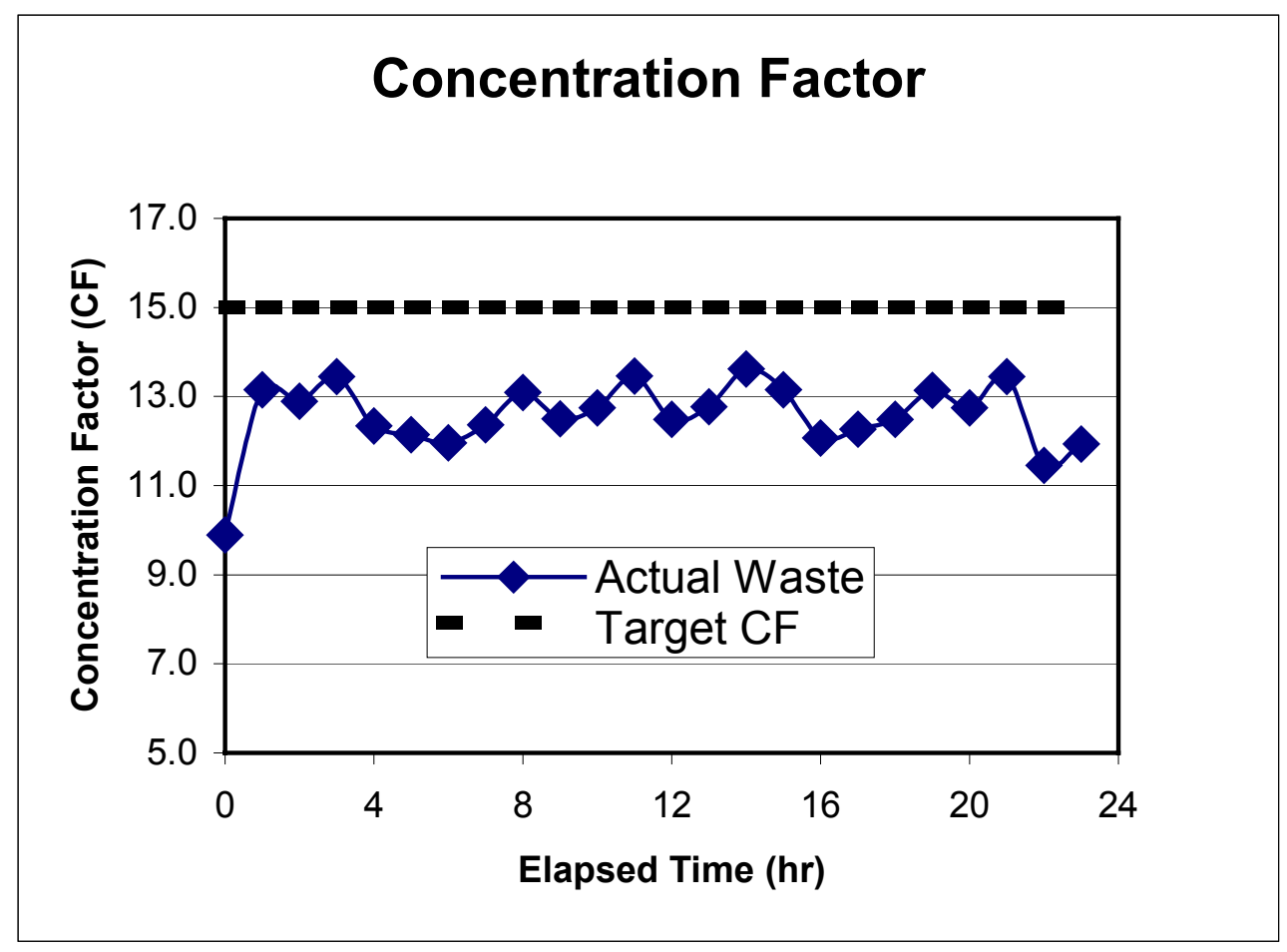

FIGURE 7. CF Values During the Tank 37H/44F Composite Waste Test 


\subsubsection{Second Phase Carryover}

Researchers estimated the second phase carryover for the Tank $37 \mathrm{H} / 44 \mathrm{~F}$ composite waste test from the volume of solvent (or aqueous) that accumulated in the process decanters during the 24 hour test duration. Table $\mathrm{V}$ lists the estimated minor phase volume in each decanter and the calculated carryover for each stream.

The majority of the minor phase carryover is expected to accumulate in the decanters. However, losses occur from the decanters due to entrained droplets and solubility in the aqueous stream. Table VI lists results of measurements of solvent components in the aqueous streams leaving the decanters (D1, D-3, and D-4). These represent solvent losses in addition to the carryover amounts listed in Table $\mathrm{V}$.

TABLE V. Second Phase Carryover for Tank 37H/44F Composite Waste Test

$\begin{array}{clcc}\text { Decanter } & \text { Stream } & \begin{array}{c}\text { Accumulated } \\ \text { Volume }\end{array} & \begin{array}{c}\text { Carryover* } \\ \text { (vol \%) }\end{array} \\ \text { D-1 } & \text { Waste raffinate } & \frac{(\mathbf{m L})}{<2.9} & <0.007 \\ \text { D-2 } & \text { Solvent } & <3.2 & <0.02 \\ \text { D-3 } & \text { Strip raffinate } & 6 & 0.20 \\ \text { D-4 } & \text { Wash raffinate } & 6 & 0.15\end{array}$

*Calculated based on the following flow rates during the 24-hour test: Waste raffinate, 32 $\mathrm{mL} / \mathrm{min}$; Solvent, $11.5 \mathrm{~mL} / \mathrm{min}$; Strip raffinate, $2.1 \mathrm{~mL} / \mathrm{min}$; and Wash raffinate, 2.8 $\mathrm{mL} / \mathrm{min}$.

TABLE VI. Solvent Components in Aqueous Process Streams

\begin{tabular}{|c|c|c|c|c|}
\hline \multirow[t]{2}{*}{$\underline{\text { Stream }}$} & \multirow{2}{*}{$\begin{array}{l}\text { Elapsed } \\
\text { Time (h) } \\
\end{array}$} & \multicolumn{2}{|c|}{ Concentration $(\mathrm{mg} / \mathrm{L})$} & \multirow{2}{*}{$\begin{array}{c}\text { Entrainment } \\
(\text { vol\%) }\end{array}$} \\
\hline & & $\underline{\text { BOBCalix }}$ & $\underline{\text { Modifier }}$ & \\
\hline \multirow[t]{3}{*}{ D-1 Waste raffinate } & 2 & $<5$ & 56.5 & 0.022 \\
\hline & 13 & $<10$ & 37.9 & 0.015 \\
\hline & 23 & $<10$ & 50.5 & 0.020 \\
\hline \multirow[t]{3}{*}{ D-3 Strip raffinate } & 3 & $<5$ & 5.5 & 0.002 \\
\hline & 14 & $<5$ & 33.3 & 0.013 \\
\hline & 24 & $<5$ & 81.3 & 0.032 \\
\hline \multirow[t]{3}{*}{ D-4 Wash raffinate } & 1 & $<10$ & 28.1 & 0.011 \\
\hline & 12 & $<10$ & 33.8 & 0.013 \\
\hline & 22 & $<10$ & 27.5 & 0.011 \\
\hline
\end{tabular}




\subsubsection{Solvent Condition and Impurities}

The solvent inventory underwent 17.3 turnovers over the course of the 24-hour test. Samples of the solvent were obtained at the start and end of the 24 hour test period. Table VII lists results of analyses for the solvent components and impurities. The nominal composition of the initial solvent is $7 \mathrm{mM}$ BOBCalix, $0.75 \mathrm{M}$ modifier, and $3.0 \mathrm{mM}$ TOA.

\subsubsection{Organic Compounds in Aqueous Streams}

Waste raffinate, strip effluent, and solvent wash solution samples were analyzed for minor organic compounds by GC-MS methods. Table VIII lists the results. In most cases, nothing was found above the detection limit of the analytical method.

\subsubsection{Stage Data}

The high concentration of ${ }^{137} \mathrm{Cs}$ in the Tank $37 \mathrm{H} / 44 \mathrm{~F}$ composite waste allowed calculation of distribution coefficients in all stages. Table IX lists the measured cesium concentration data and the calculated distribution coefficients $\left(\mathrm{D}_{\mathrm{Cs}}\right)$ from the stage samples drained from the individual stages at the end of the contactor test. The cesium distribution data were measured at $22.3{ }^{\circ} \mathrm{C}$

\section{TABLE VII. Solvent Composition and Minor Components}

\section{Component}

$\underline{\text { Solvent components }}$

BOBCalix

Modifier

Trioctylamine

\section{Concentration}

Initial

Final

$7.6 \mathrm{mM}$

$7.0 \mathrm{mM}$

$0.82 \mathrm{M}$

$0.78 \mathrm{M}$

$3.1 \mathrm{mM}$

$3.1 \mathrm{mM}$

$\underline{\text { Solvent degradation products }}$

Dioctylamine

sec-Butylphenol

$<10 \mathrm{mg} / \mathrm{L}$

$<10 \mathrm{mg} / \mathrm{L}$

$11 \mathrm{mg} / \mathrm{L}$

$<10 \mathrm{mg} / \mathrm{L}$

Potential waste components

Trimethylamine

Tributylphosphate

$<10 \mathrm{mg} / \mathrm{L}$

$<100 \mathrm{mg} / \mathrm{L}$

$<10 \mathrm{mg} / \mathrm{L}$

$<100 \mathrm{mg} / \mathrm{L}$

$<100 \mathrm{mg} / \mathrm{L}$

$<100 \mathrm{mg} / \mathrm{L}$

Radionuclides
${ }^{137} \mathrm{Cs} \quad(\mathrm{d} / \mathrm{m} / \mathrm{mL})$
$4.7 \times 10^{4}$
$4.4 \times 10^{4}$ 
TABLE VIII. Organic Compounds in Aqueous Streams

$\underline{\text { Stream }}$

Waste raffinate

Strip effluent

Solvent wash
Elapsed

$\underline{\text { Time (h) }}$
BuOH Concentration $(\mathrm{mg} / \mathrm{L})$

BuOH TBP TOA DOA TMA SBP

$<1 \quad<1$

$$
1.9
$$

$<1<1$

$0.19<1<1$

0.0025

$<1<1$

0.8

$<0.11<0.11<0$
$<0.12<0.12$
$<0.15<0.15$

$<0.11<0.11<0.11<0.11$

3
14

$0.09<0$.

$0.33<0.15<0.15<0.15$

$\begin{array}{ll}<1 & <1 \\ <1 & <1 \\ <1 & <1\end{array}$

$0.26<$

$0.18<1$

$\begin{array}{ll}<1 & <1 \\ <1 & 0.035 \\ <1 & 0.075\end{array}$

*Results reported as less than the detection limit (e.g, $<1)$ indicate no evidence for the presence of the compound. Numerical results that are smaller than the detection limit are of uncertain accuracy, but the GC trace showed evidence that the compound was present.

TABLE IX. Stage Sample Cesium Distribution Coefficients

\begin{tabular}{|c|c|c|c|c|c|}
\hline \multirow[t]{2}{*}{$\underline{\text { Process }}$} & \multirow[t]{2}{*}{$\underline{\text { Stage }}$} & \multicolumn{2}{|c|}{ Cs Concentration (M) } & \multicolumn{2}{|c|}{$\underline{D}_{\mathrm{Cs}}\left(\right.$ at $\left.\left.^{\circ} \mathrm{C}\right)\right)$} \\
\hline & & $\underline{\text { Aqueous }}$ & Organic & $\underline{\text { Measured }}$ & Corrected \\
\hline Wash & W & $1.68 \mathrm{E}-9$ & $4.66 \mathrm{E}-9$ & $2.8(22.3)$ & \\
\hline \multirow[t]{7}{*}{ Extraction } & 1 & $2.65 \mathrm{E}-10$ & 4.07E-9 & $15.4(22.3)$ & $13.7(24.0)$ \\
\hline & 3 & $1.31 \mathrm{E}-9$ & $2.00 \mathrm{E}-8$ & $15.2(22.3)$ & $13.6(24.0)$ \\
\hline & 5 & $5.66 \mathrm{E}-9$ & $8.50 \mathrm{E}-8$ & $15.0(22.3)$ & $13.4(24.0)$ \\
\hline & 7 & $3.52 \mathrm{E}-8$ & $4.99 \mathrm{E}-7$ & $14.2(22.3)$ & $12.7(24.0)$ \\
\hline & 9 & $2.54 \mathrm{E}-7$ & $3.37 \mathrm{E}-6$ & $13.3(22.3)$ & $11.9(24.0)$ \\
\hline & 13 & $1.53 \mathrm{E}-5$ & $1.65 \mathrm{E}-4$ & $10.8(27.6)$ & $13.6(24.0)$ \\
\hline & 15 & $1.21 \mathrm{E}-4$ & $9.70 \mathrm{E}-4$ & $8.0(27.6)$ & $10.1(24.0)$ \\
\hline \multirow[t]{2}{*}{ Scrub } & 16 & $5.22 \mathrm{E}-4$ & $1.13 \mathrm{E}-3$ & $2.16(27.6)$ & $0.84(36.0)$ \\
\hline & 17 & $7.47 \mathrm{E}-4$ & $6.82 \mathrm{E}-4$ & $0.91(27.6)$ & $0.41(36.0)$ \\
\hline \multirow[t]{8}{*}{ Strip } & 18 & $1.64 \mathrm{E}-3$ & $5.37 \mathrm{E}-4$ & $0.33(27.6)$ & $0.11(38.0)$ \\
\hline & 20 & $4.39 \mathrm{E}-4$ & $6.80 \mathrm{E}-5$ & $0.16(27.6)$ & $0.052(38.0)$ \\
\hline & 22 & $8.47 \mathrm{E}-5$ & $1.12 \mathrm{E}-5$ & $0.13(27.6)$ & $0.045(38.0)$ \\
\hline & 24 & $1.28 \mathrm{E}-5$ & $1.44 \mathrm{E}-6$ & $0.11(27.6)$ & $0.038(38.0)$ \\
\hline & 26 & $8.73 \mathrm{E}-7$ & $1.47 \mathrm{E}-7$ & $0.17(22.3)$ & $0.032(38.0)$ \\
\hline & 28 & $8.87 \mathrm{E}-8$ & $1.52 \mathrm{E}-8$ & $0.17(22.3)$ & $0.032(38.0)$ \\
\hline & 30 & $2.19 \mathrm{E}-8$ & $3.17 \mathrm{E}-9$ & $0.14(22.3)$ & $0.026(38.0)$ \\
\hline & 32 & $6.47 \mathrm{E}-9$ & $8.52 \mathrm{E}-10$ & $0.13(22.3)$ & $0.025(38.0)$ \\
\hline
\end{tabular}


(Stages 1 through 9 and 26 through 32) and at $27.6{ }^{\circ} \mathrm{C}$ (Stages 13 through 24). The $\mathrm{D}_{\mathrm{Cs}}$ values were corrected to the stage temperatures measured during the test (see Section 5.2.9) using the following enthalpies measured by L. H. Delmau of ORNL for the optimized solvent: extraction, $-48.9 \mathrm{~kJ} / \mathrm{mole}$; first scrub, $-86.8 \mathrm{~kJ} / \mathrm{mole}$; second scrub, $-74.2 \mathrm{~kJ} / \mathrm{mole}$; and strip, $-81.1 \mathrm{~kJ} / \mathrm{mole}$. These are similar to previously reported temperature dependence data for the older solvent composition. ${ }^{10}$

Researchers estimated the stage efficiencies by comparing the cesium concentration data in Table IX to calculated concentrations obtained from the Spreadsheet Algorithm for Stagewise Solvent Extraction (SASSE). ${ }^{13}$ Input data for the SASSE calculations include flow rates, cesium concentrations in feed streams, cesium distribution coefficients, and stage efficiencies. Extraction, scrub, and strip $\mathrm{D}_{\mathrm{Cs}}$ values were not measured for the Tank $37 \mathrm{H} / 44 \mathrm{~F}$ waste with optimized solvent in independent batch tests. Therefore, the stage data results listed in Table $\mathrm{X}$ were used in the efficiency calculations. SASSE-calculated cesium concentrations for each stage at 5\% efficiency increments were compared to the measured stage concentrations. The comparison is based on the slope of the lines through the predicted and measured values and not on the overlap of the predicted values with the measured data points. The slopes match well with extraction stage efficiencies of $80 \%$ and strip stage efficiencies of $80 \%$. Figure 8 shows the SASSE results and contains the waste raffinate, strip effluent, and stripped solvent cesium concentrations from the end of the test, plotted against the stage from which the streams exit the contactor apparatus.

\section{TABLE X. Parameter Values Used in SASSE Calculation}

$\begin{array}{llccc}\text { Section } & \underline{\text { Stages }} & \begin{array}{c}\text { Temperature } \\ \left({ }^{\circ} \mathbf{C}\right)\end{array} & \underline{\underline{\mathbf{D}} \mathbf{C S}} & \begin{array}{c}\text { Efficiency } \\ \mathbf{( \% )}\end{array} \\ \text { Extraction } & 1 \text { through } 15 & 24 & 12.7^{* *} & 80 \\ \text { Scrub } & 16 & 36 & 0.84 & 80 \\ & 17 & 36 & 0.41 & 80 \\ \text { Strip } & 18 & 38 & 0.110 & 80 \\ & 19 & 38 & 0.052 & 80 \\ & 20-32 & 38 & 0.036^{* *} & 80\end{array}$

* Obtained from Table IX.

** Averaged stage sample data. 


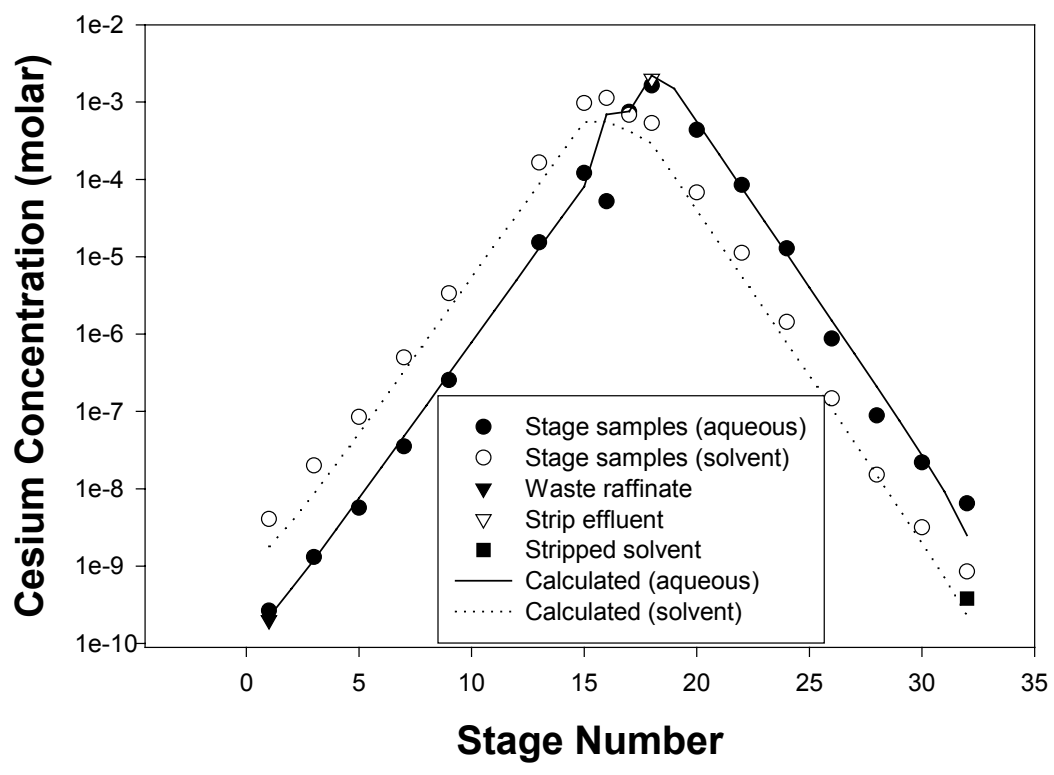

FIGURE 8. Comparison of Stage Sample Data and SASSE Calculations

\subsubsection{Stage Temperatures}

Thermocouples attached to the outside of contactor stages in each section of the test apparatus measured temperatures during the test campaign. The temperatures in each section remained fairly stable within the ranges shown in Table XI. It should be noted that the wash stage temperature is included in the extraction section temperature range. Typically, temperatures for stages where process streams enter the contactors are significantly higher or lower than other stages in that section. For example, Stage 1 typically measured 25 to $26{ }^{\circ} \mathrm{C}$ compared to 21 to $24^{\circ} \mathrm{C}$ for other extraction stages.

TABLE XI. Temperature Ranges for Contactor Sections.

\begin{tabular}{|l|l|l|}
\hline $\begin{array}{c}\text { Contactor } \\
\text { Section }\end{array}$ & \multicolumn{1}{|c|}{ Target $\left({ }^{\circ} \mathbf{C}\right)$} & $\begin{array}{c}\text { Temperature } \\
\text { Range }\left({ }^{\circ} \mathbf{C}\right)\end{array}$ \\
\hline Extraction & $>20$ and $<25$ & $21-26$ \\
\hline Scrub & $>20$ & $30-37$ \\
\hline Strip & $>20$ & $33-40$ \\
\hline
\end{tabular}


WSRC-TR-2002-00243, REV. 0

\subsection{DISCUSSION}

\subsection{TANK 37H/44F COMPOSITE WASTE COMPOSITION}

The Tank 37H/44F composite sample used in the present test proved similar to the previous batch processed with the old solvent composition. ${ }^{1}$ This was expected since the original tank samples were used for both tests and differed only in minor variations of the dilution process. The diluted waste composition is typical of tank supernates. Free hydroxide accounts for more than half of the total sodium concentration. The diluted Tank 37H/44F composite waste contained $4.1 \mathrm{M}$ free hydroxide compared to $2.0 \mathrm{M}$ free hydroxide in average waste. ${ }^{14}$ Nitrate $(0.57 \mathrm{M})$ is correspondingly low compared to the expected average concentrations $(1.7 \mathrm{M})$. The ${ }^{137} \mathrm{Cs}$ activity of the diluted sample $\left(1.58 \times 10^{9} \mathrm{~d} / \mathrm{m} / \mathrm{mL}\right.$ or $\left.0.71 \mathrm{Ci} / \mathrm{L}\right)$ exceed the value for average waste $(0.37 \mathrm{Ci} / \mathrm{L})$. Potassium ion $(0.035 \mathrm{M})$, which competes with cesium during extraction, is also higher than average $(0.014 \mathrm{M})$. The high concentrations of these two components makes decontamination of the Tank $37 \mathrm{H} / 44 \mathrm{~F}$ waste more challenging than average waste.

\subsection{HYDRAULIC PERFORMANCE}

The contactor test apparatus operated without interruption in a hydraulically stable condition throughout the final two of the three spiked simulant tests and for the entire 24 hour actual waste demonstration. However, there were significant hydraulic problems encountered in the first spiked simulant test. Hydraulic upsets were caused primarily by interstage lines in the strip section that had become bent. There was also a rotor in the extraction section that operated unreliably and a rotor in the strip section that completely failed (just prior to the final spiked simulant test). Both rotors were subsequently replaced. Throughout the test campaign, there were difficulties with flow measurement and control. Extended deployment of the test apparatus in the shielded cells facility left the test rig with flow instrumentation that operated unreliably. The instrument issues, coupled with the relative difficulty in obtaining timed flow collections (possible hydraulic upset of operations), created a great deal of uncertainty about which flow indications should be trusted. In spite of these challenges, the test apparatus did run in a hydraulically stable fashion for an extended period of time. In fact, the test apparatus was operated continuously (with non-radioactive Tank 37H/44F simulant feed) in the interim between the final spiked simulant test and the actual waste demonstration when samples from the spiked simulant test were being analyzed. This continuous operation allowed for further verification of stable hydraulic operation, as well as providing another six hours of "rinsing" during which the apparatus could be further decontaminated in preparation for the actual waste demonstration. In total, the test apparatus operated for nearly 35.5 hours under stable hydraulic conditions.

\subsection{SECOND PHASE CARRYOVER}

Second phase carryover is defined as an unwanted liquid phase exiting in a primary product stream (e.g., the organic solvent exiting in the aqueous waste raffinate stream). Secondary phase carryover is directly related to hydraulic performance. Excessive second phase carryover is indicative of poor hydraulic performance and can lead to large losses of solvent.

Page 22 of 38 
Based on measurements performed on all four decanters (Table VI), second phase carryover was maintained below $1 \mathrm{vol} \%$ for the entire test campaign. There was no visible second phase accumulation in either the waste raffinate decanter (D-1) or the stripped solvent decanter (D-2). These observations indicate a second phase carryover that is essentially zero. In the strip raffinate decanter (D-3) and wash receipt decanter (D-4), the second phase carryovers were estimated $0.20 \%$ and $0.15 \%$, respectively. These low values for second phase carryover are another indication of the excellent hydraulic performance observed during the demonstration.

Table XII lists the total second phase carryover based on the decanter measurements (Table V) and the sample analyses (Table VI). In all cases, minor phase carryover in all process streams was maintained well below the process objective of $<1.0 \mathrm{vol} \%$. The losses that escape the decanter may be due to entrainment that was not captured by the decanter or to the solubility of solvent components in the aqueous process stream. The observed values greatly exceed the partition coefficients ${ }^{15}$ previously measured for solvent components in simulated waste, suggesting that the compounds are present due to entrainment rather than solubility. The measured partition coefficients suggest that modifier concentrations due to solubility should be less than $5 \mathrm{mg} / \mathrm{L}$.

\subsection{WASTE AND SOLVENT DECONTAMINATION}

One of the main indicators of process performance is the waste decontamination factor. Waste feed entering Stage 15 is blended with scrub solution, contacted with the solvent, and exits Stage 1. The degree of extraction is affected by hydraulic performance, stage temperature, stage efficiency, and residual cesium concentration in the solvent feed. The DF required for Tank $37 \mathrm{H} / 44 \mathrm{~F}$ composite waste to meet the Saltstone WAC for ${ }^{137} \mathrm{Cs}(<45$ $\mathrm{nCi} / \mathrm{g}$ ) equaled 12,400. The higher target DF of 40,000 ensures ample process robustness and allows comparison of system performance with previous test campaigns.

\section{TABLE XII. Combined Minor Phase Carryover Results*}

$\begin{array}{cllll}\underline{\text { Decanter }} & \text { Stream } & \begin{array}{l}\text { Decanter } \\ \text { (vol \%) }\end{array} & \begin{array}{l}\text { Maximum } \\ \text { Entrainment } \\ \text { (vol \%) }\end{array} & \begin{array}{l}\text { Total } \\ \text { (vol \%) }\end{array} \\ \text { D-1 } & \text { Waste raffinate } & <0.007 & 0.019 & \leq 0.026 \\ \text { D-2 } & \text { Solvent } & <0.02 & -- & <0.02 \\ \text { D-3 } & \text { Strip raffinate } & 0.20 & 0.016 & 0.22 \\ \text { D-4 } & \text { Wash raffinate } & 0.15 & 0.012 & 0.16\end{array}$

*See Tables V and VI. 
Solvent decontamination in the stripping section is also important. If sufficient stripping of the cesium-loaded solvent does not occur (low solvent DFs) cesium in the solvent is recycled back to the contactor bank and reduces the maximum attainable waste DF. Again, the higher target DF of 40,000 ensures ample process robustness and allows comparison of system performance with previous test campaigns.

\subsubsection{Spiked Simulant Testing}

The spiked simulant test results verified that radioactive operations could be successfully performed under stable hydraulic conditions using the optimized solvent mixture. Upon resolution of various hardware issues (i.e., bent interstage lines and failed rotors), the hydraulic performance of the system was acceptable. The decontamination factors were somewhat lower $\left(\sim 10^{3}\right)$ than the target value of 40,000 , but the waste raffinate was decontaminated to the supposed contamination limit (background) achievable in the cells (at the end of the test, the waste raffinate activity was approximately $1 \times 10^{3} \mathrm{~d} / \mathrm{m} / \mathrm{mL}$ to $2 \times 10^{3}$ $\mathrm{d} / \mathrm{m} / \mathrm{mL}$ ). Furthermore, it was anticipated that the higher concentration of cesium in the feed for the actual waste demonstration would lead to acceptable DFs. The spiked simulant tests also allowed an opportunity to train new personnel and retrain experienced personnel in preparation for the actual waste demonstration. The latter point was of particular concern due to high levels of background contamination encountered during test preparation which necessitated great care in sample handling.

\subsubsection{Tank 37H/4F Waste Decontamination}

Waste decontamination factors from the actual waste demonstration show excellent verification of the process efficacy for removing cesium. Waste DF values as high as 1.37 million were achieved during the 24 hours of operation with an average DF value of 630,000 during operations at flow rates approximating the process baseline. This average DF value is 16 times greater than the process target of 40,000 and 50 times greater than the value of 12,400 necessary to meet the Saltstone WAC. These DF values are somewhat lower than values obtained for the same waste feed using the original solvent formulation in FY-2001. ${ }^{1}$ In that demonstration, the average DF obtained during the first 27 hours of stable operation was 1.46 million. This result is not surprising, however. The optimized solvent mixture used in this demonstration has a lower concentration of the BOBCalix extractant. Therefore, it is expected that the average waste DF would be lower. The optimized solvent mixture produces $\mathrm{D}_{\mathrm{Cs}}$ values that are approximately $12 \%$ lower than those of the original solvent formulation. $^{20}$ SASSE calculations indicate that this difference in the $\mathrm{D}_{\mathrm{Cs}}$ values would account for approximately $80 \%$ of the difference between the average DF values for the two solvent mixtures. The remainder of the difference is likely caused by the marginal strip section performance. Solvent leaving the strip section and recycled to the process contained small amounts of cesium that limited the achievable waste DF. Therefore, it is more appropriate to compare the solvent performance against process goals, rather than performance of the previous solvent mixture. From the perspective of achieving process goals, process performance measured by waste decontamination was excellent during this demonstration. It can, therefore, be concluded that the optimized solvent mixture is capable of successfully decontaminating HLW supernate solutions.

Page 24 of 38 
WSRC-TR-2002-00243, REV. 0

\subsubsection{Solvent Decontamination}

Solvent decontamination is an important part of overall system performance. If the solvent is not adequately decontaminated in the stripping section, solvent containing cesium recycles to the extraction section and limits the maximum attainable waste DF. This situation occurred during the actual waste demonstration. Marginal strip section performance, presumably caused by a low strip feed rate, resulted in a slow increase in the cesium concentration in the solvent reservoir. This trend is clearly manifest in the solvent DF behavior over the initial 15 hours of the test. The initial solvent DF was approximately 400,000. However, it decreased steadily with time. At 15.1 hours, researchers increased the strip feed rate and the solvent DF recovered rapidly. By the end of the test at 24 hours, the solvent DF recovered completely to its initial value. The waste DF trended similarly to the solvent DF since cesium that does not strip from the solvent limits the maximum waste DF. The response in waste DF was muted compared to the solvent DF because the solvent flowed into a reservoir before returning to the extraction stages.

Possible causes of the marginal strip section performance include the following.

(1) Inadequate $\mathrm{O} / \mathrm{A}$ ratio in strip section.

The calculated strip section O/A ratio (based on data in Table IV) was 5.7 to

6.1 in the first 15 hours and 5.3-5.5 during the last 9 hours. The previous

Tank $37 \mathrm{H} / 44 \mathrm{~F}$ test operated at a strip section $\mathrm{O} / \mathrm{A}$ ratio of 4.9. Although the difference is significant, SASSE calculations do not indicate that the higher $\mathrm{O} / \mathrm{A}$ was inadequate.

(2) Gradual decrease in strip solution feed rate.

This will cause a gradual increase in the strip section $\mathrm{O} / \mathrm{A}$ ratio and $\mathrm{D}$ values and a decrease in cesium stripping, resulting in more cesium in the stripped solvent. Increasing the strip solution flow rate will reverse the trend as observed during the test. However, the available flow rate data do not indicate a slow decrease occurred during the first 15 hours of the test, although the low precision of the measurements may hide the trend. In addition, the gradual recovery is unexpected since previous testing showed steady state operation normally attains within 1-2 hours after a change in flow rate.

(3) Gradual accumulation of an interfering chemical.

Certain chemicals, such as soaps and surfactants found in radioactive waste, can accumulate in the solvent and interfere with cesium stripping. Although it seems unlikely, the small change in strip solution flow rate at 15 hours could have tipped the balance so that more of the interfering compound was being stripped from the solvent than was accumulating from the waste. This mechanism is compatible with the slow onset and recovery.

(4) Low strip stage efficiency.

The low strip solution flow rate could lower strip stage efficiency if the low flow rate caused incomplete filling of the individual stages. Increasing the flow rate would correct the problem as observed in the test. However, the small change in flow rate and the long time required to reach steady stage argue against this interpretation.

Page 25 of 38 


\subsubsection{Concentration Factor}

The cesium removed from the waste feed by the solvent is stripped from the solvent in the strip section and concentrated in the aqueous strip raffinate. The target CF for cesium in the strip raffinate for this test campaign was 15 . Based on the measured flow rates listed in Table IV, the observed CF should have been 14.8 during the majority of the test duration. The average observed CF over the 24 hours of operation was 12.7 , or $15 \%$ less than the target value. The low observed value suggests a bias in one of the flow rate measurements or possibly a systematic error in counting the feed or strip solution cesium activity.

\subsection{SOLVENT CONDITION AND IMPURITIES}

The solvent condition did not change significantly during the 24 hour test. The modifier, extractant, and suppressor concentrations at the beginning and end of the test agreed with each other and with the theoretical solvent composition within the error $( \pm 10 \%)$ of the HPLC measurements (Table VIII). The cesium activity in the solvent remained virtually unchanged during the test. With the exception of DOA, no significant amounts of organic or inorganic impurities were found in either the initial or final solvent samples. DOA was found in final solvent sample at slightly above the detection limit of the analysis. The low level of DOA suggests about $1 \%$ decomposition of the TOA in the initial solvent. However, since the value is close to the detection limit, the potential error is large. DOA was not detected in the previous Tank $37 \mathrm{H} / 44 \mathrm{~F}$ test with the older solvent composition, ${ }^{19}$ but that solvent composition contained less TOA. Future testing should attempt to confirm this observation by employing increased quality assurance measures to ensure the sample integrity and analytical accuracy.

\subsection{ORGANIC COMPOUNDS IN AQUEOUS STREAMS}

The three aqueous effluent streams (waste raffinate, strip effluent, and solvent wash) were analyzed for organic compounds from the solvent (TOA), from the waste (TMA, TBP, and $\mathrm{BuOH}$ ), or from decomposition of the solvent (DOA and SBP). TOA and SBP occurred above the analytical detection limits in several instances (Table IX).

TOA, a component of the solvent, showed up in all three streams. TOA was not observed in previous testing, but its higher concentration in the optimized solvent may result in its presence in this test. The observed concentrations coupled with the stream flow rates suggest loss of about $4 \%$ of the TOA in the original solvent inventory (likely too small a change to be observed in the final solvent sample). Future testing should attempt to confirm this observation by employing increased quality assurance measures to ensure the sample integrity and analytical accuracy. Long-term contact tests between optimized solvent and simulated waste are recommended.

SBP, a decomposition product from the modifier, was observed in the waste raffinate and solvent wash solutions. However, the amounts were very small and do not represent a significant loss of modifier $\left(\sim 5 \times 10^{-4} \%\right)$.

Page 26 of 38 


\subsection{STAGE SAMPLES}

Testing with Tank 37H/44F composite waste enabled measurements of the distribution coefficients for all process stages (Table $\mathrm{X})$. The $\mathrm{D}_{\mathrm{Cs}}$ values for the extraction stages $(12.7 \pm$ $1.3)$ and for the strip stages $(0.0357 \pm 0.0099)$ were relatively constant. After correcting for temperature differences, the stage sample values were averaged and used in the efficiency calculations. The individual stage sample values for the two scrub stages and the first strip stage were used as measured and without averaging.

The extraction stage efficiency of $80 \%$ efficiency was slightly lower than previously measured values for optimized solvent, but equaled the process objective of $80 \%$. Leonard ${ }^{16}$ obtained $85 \%$ efficiency using 2 -cm contactors with the optimized solvent and simulated waste. SRTC researchers obtained $90 \%$ efficiency with optimized solvent and Tank $37 \mathrm{H}$ dissolved salt cake waste. ${ }^{2}$ In comparison, SRTC researchers obtained $84 \pm 4 \%$ efficiency with the old solvent composition and Tank $37 \mathrm{H} / 44 \mathrm{~F}$ composite waste. ${ }^{1}$

The strip efficiency of $80 \%$ is also less than Leonard's value of $92 \%$ with simulated waste, but, again, equals the process objective of $80 \%$. Previously, SRTC researchers obtained $80 \%$ efficiency with optimized solvent and Tank $37 \mathrm{H}$ dissolved salt cake waste. ${ }^{3}$ Strip efficiency of the old solvent with Tank $37 \mathrm{H} / 44 \mathrm{~F}$ composite waste equaled $82 \pm 4 \%$. 


\subsection{CONCLUSIONS}

Researchers demonstrated the CSSX process flow sheet for the decontamination of Tank $37 \mathrm{H} / 44 \mathrm{~F}$ composite high-level waste supernate solution using an optimized solvent mixture in a 33-stage, 2-cm centrifugal contactor apparatus at the Savannah River Technology Center. Three tests employing a simulated Tank $37 \mathrm{H} / 44 \mathrm{~F}$ composite solution demonstrated proper hydraulic operation and decontaminated the spiked simulant solution to background levels. A subsequent 24 hour demonstration processed $45 \mathrm{~L}$ of actual Tank $37 \mathrm{H} / 44 \mathrm{~F}$ composite waste. Test results support the following conclusions.

Hydraulic Performance: Contactor operation using Tank 37H/44F composite supernate and optimized solvent demonstrated acceptable hydraulic performance. When bent interstage lines were straightened and malfunctioning rotors were replaced, the spiked simulant tests and actual waste demonstration proceeded uninterrupted for the remainder of the test campaign.

Solvent Retention: Carryover of organic solvent in aqueous streams (and aqueous in organic streams) was much less than $1 \%$ when processing actual Tank $37 \mathrm{H} / 44 \mathrm{~F}$ composite supernate waste. Analysis of process streams indicates only minor amounts of entrainment occurs.

Waste Decontamination: The CSSX process employing the optimized solvent mixture is capable of reducing the concentration of ${ }^{137} \mathrm{Cs}$ in high-level supernate solution to below the Saltstone process requirement of $45 \mathrm{nCi} / \mathrm{g}$. The Tank $37 \mathrm{H} / 44 \mathrm{~F}$ composite feed required a DF of 12,400 to meet the Saltstone process requirement. During this test $45 \mathrm{~L}$ of Tank $37 \mathrm{H} / 44 \mathrm{~F}$ composite supernate solution were processed, and the composite met the Saltstone requirement. The process achieved DFs as high as 1.37 million. DF values averaged 520,000 over the 24 hour test period.

Cesium Concentration: The process produced an average CF of 12.7 using Tank 37H/44F composite supernate solution and optimized solvent. The CF value is approximately $15 \%$ less than the target $\mathrm{CF}$ value of 15 . However, the reduced cesium concentration performance likely results from uncertainties in process flow measurement and control in the strip section. 


\subsection{FUTURE WORK}

It is recommended that future work be performed with dissolved salt cake waste. Although other work has been performed that suggests that salt cake waste can be successfully processed by the CSSX process ${ }^{2}$, that data set is limited by marginal strip section performance and dissolved salt cake feed that was not greatly different in composition from supernate solutions used in previous tests ${ }^{1}$. It is recommended that future testing be performed with salt cake feed that is relatively low in hydroxide $(<3 \mathrm{M})$ and cesium, and high in nitrate and nitrite.

It is also recommended that future work focus upon better management of scrub and strip section performance. The current study was challenged with considerable uncertainty in flow measurement and control. That uncertainty creates difficulty in discerning whether marginal strip section performance is due to process fluid flows or process chemistry.

Finally it is recommended that a major overhaul of the 2-cm centrifugal contactor apparatus be performed. Long-term deployment of the test apparatus in the shielded facility has resulted in significant wear on many components. The test apparatus should be thoroughly cleaned and all electronic instrumentation should be replaced where practical. Also, all pumps, tubing and fittings should be inspected and replaced where possible. 


\subsection{ACKNOWLEDGEMENTS}

The authors thankfully acknowledge the helpful discussions and leadership provided by Major C. Thompson of SRTC who is the Tank Focus Area Technical Lead for the CSSX process. In addition, we thank Lucy Beasely, Jane Howard, Maurice Lee, and Nan Stanley, and Martha Holmes for their dedication and support in operating the test apparatus within the shielded facility. Babb Attaway, Carolyn Conley, Ron Blessing, and Gary Hall provided additional shielded facility support. Shirley McCollum, Betty Croy, and Mona Blume provided support outside of the shielded facility. Cecilia DiPrete, David DiPrete and Teresa Eddy of ADS provided the radionuclide counting support, in many cases with very short turnaround times. Thomas White and Steve Crump helped plan and then performed the organic component analyses. L. H. Delmau of ORNL provided the enthalpy values needed for $\mathrm{D}_{\mathrm{Cs}}$ temperature corrections. 


\subsection{REFERENCES}

1. S. G. Campbell, M. W. Geeting, C. W. Kennell, J. D. Law, R. A. Leonard, M. A. Norato, R. A. Pierce, T. A. Todd, D. D. Walker, and W. R. Wilmarth, "Demonstration of CausticSide Solvent Extraction with Savannah River Site High Level Waste," WSRC-TR-200100223, Revision 0, April 19, 2001.

2. Bonnesen, Peter V., et. al., Alkaline-Side Extraction of Cesium from Savannah River Tank Waste Using a Calixarene-Crown Ether Extractant, ORNL/TM-13704, 1998.

3. M. A. Norato, S. D. Fink, F. F. Fondeur, G. F. Kessinger, R. A. Pierce, and D. D. Walker, "Demonstration of Caustic-Side Solvent Extraction with Optimized Solvent in the 2-cm Centrifugal Contactor Apparatus Using Dissolved Salt Cake from Tank 37H," WSRC-TR2002-00307, Revision 0, August 23, 2002.

4. Delmau, Laetitia H., et. al., Improved Performance of the Alkaline-Side CSEX Process for Cesium Extraction from Alkaline High-Level Waste Obtained by Characterization of the Effect of Surfactant Impurities, ORNL/TM-1999/209, 1999.

5. L. H. Delmau, T. J. Haverlock, and B. A. Moyer, "Caustic-Side Solvent Extraction: AntiCaking Surfactants Found to Be Cause of Apparent Effect of High Nitrite Concentration on Cesium Stripping," ORNL/TM-2002/104, May 2002.

6. Westinghouse Savannah River Company, "Operating Plan for Tank 37H Waste Transfer," U-ESR-H-00039, Rev. 2, 2002.

7. M. A. Norato, "Task Technical and Quality Assurance Plan for Solvent Extraction Actual Waste Testing - 2-cm Centrifugal Contactor Testing for Optimized CSSX Solvent and Dissolved Saltcake Actual Waste Feed," WSRC-RP-2001-00999, Rev. 0, December 12, 2001.

8. S. D. Fink, D. T. Hobbs, M. A. Norato, T. B. Peters, and D. D. Walker, "Demonstration of MST and Permanganate Efficiency on Removal of Actinides and Strontium from Savannah River Site High Level, Waste, " WSRC-TR-2002-00355, August 2002.

9. D. D. Walker, “CSSX Contactor Operation (U)," WSRC L12.1, Procedure IWT-OP-136, Rev. 1, March 20, 2001.

10. P. V. Bonnesen, L. H. Delmau, B. A. Moyer, and R. A. Leonard, "A Robust AlkalineSide CSEX Solvent Suitable for Removing Cesium from Savannah River High Level Waste," Solvent Extraction and Ion Exchange, 18, 1079 (2000)

11. W. R. Wilmarth, D.P. Healy, D. J. Wheeler, J. T. Mills, V. H. Dukes, D. P. DiPrete, and L. H. Delmau, "CSSX Batch Measurements for SRS High Level Waste Samples and Dissolved Saltcake," WSRC-TR-2002-00336, July 19, 2002. 
12. L. H. Delmau, "Caustic-Side Solvent Extraction: Extended Equilibrium Modeling of Cesium and Potassium Distribution Behavior," ORNL/TM-2002/116, May 2002.

13. R. A. Leonard and M. C. Regalbuto, "A Spreadsheet Algorithm for Stagewise Solvent Extraction," Solvent Extraction and Ion Exchange, 12, 909 (1994).

14. R. A. Dimenna, H. H. Elder, J. R. Fowler, R. C. Fowler, M. V. Gregory, T. Hang, R. A. Jacobs, P. K. Paul, J. A. Pike, P. L. Rutland, F. G. Smith III, S. G. Subosits, G. A. Taylor, and S. G. Campbell, "Bases, Assumptions, and Results of the Flowsheet Calculations for the Decision Phase Salt Disposition Alternatives," WSRC-RP-99-00006, Rev. 1, October 9, 2000.

15. B. A. Moyer, et al, "Caustic-Side Solvent Extraction Chemical and Physical Properties Progress in FY 2000 and FY 2001," ORNL/TM-2001/285, February 2002.

16. R. A. Leonard, S. B. Aase, H. A. Arafat, C. Conner, J. R. Falkenberg, M. C. Regalbuto, and G. F. Vandegrift, "Simulant Flowsheet Test with Modified Solvent for Cesium Removal Using Caustic-Side Solvent Extraction," ANL-02/22, April 22, 2002.

17. R. A. Leonard, S. B. Aase, H. A. Arafat, C. Conner, J. R. Falkenberg, and G. F. Vandegrift, "Development of an Improved 2-cm Centrifugal Contactor for Cesium Removal from High-Level Waste," ANL-01/23, September 2001.

18. J. D. Law and T. A. Todd, "Experimental Test Plan for TTP ID72WWT21: Centrifugal Contactor Hydraulic Performance of Optimized Solvent," INEEL/EXT-02-00105, Rev. 0, January 24, 2002.

19. S. L. Crump, M. A. Norato, R. A. Pierce, R. J. Ray, D. D. Walker, and T. L. White, "Demonstration of Caustic-Side Solvent Extraction with Savannah River Site High-Level Waste: Results of Organic and Trace Component Analyses," WSRC-TR-2001-00372, Rev. 0, December 7, 2001.

20. L. N. Klatt, J. F. Birdwell, Jr., P. V. Bonneson, L. H. Delmau, L. J. Foote, D. D. Lee, R. A. Leonard, T. G. Levitskaia, M. P. Maskarinec, and B. A. Moyer, "Caustic-Side Extraction Solvent - Composition Recommendation,” ORNL/TM-2001/258, January 2001. 
WSRC-TR-2002-00243, REV. 0

\subsection{APPENDIX A}

\section{ANALYTICAL PLAN FOR THE CSSX CONTACTOR TEST USING OPTIMIZED SOLVENT AND ACTUAL WASTE}

\section{SUMMARY}

This memorandum describes the analytical plan for the Caustic Side Solvent Extraction (CSSX) contactor tests using optimized solvent and the remaining Tank 37/44 composite sample and the Tank $37 \mathrm{H}$ dissolved salt sample. The plan requires taking 282 samples for 316 analyses by Analytical Development Section (ADS) during five tests.

\section{TEST OBJECTIVES AND ANALYTICAL REQUIREMENTS}

The objectives of the tests are to demonstrate the hydraulic performance and the extraction, scrub, and strip efficiencies of the optimized solvent with actual Savanna River Site (SRS) high level radioactive waste. Five contactor test runs are planned. These are described below, highlighting the major objectives of each test and the analytical sampling and analyses required to meet the objectives. A summary is given in Table 1.

\section{Test 1: Hydraulic CapacityTest with Tank 37/44 Simulant (no Cesium)}

Test description: This test uses the 33-stage 2-cm contactor apparatus with the optimized solvent and non-radioactive simulant of the Tank 37/44 composite waste. This simulant will contain no cold cesium to prevent cesium-contamination of the apparatus. All four process steps (extraction, scrub, strip, and wash) will be tested simultaneously. Organic and aqueous stream flows will be controlled and monitored by the computerized control and data acquisition system. Flow rates will be varied and the response of the apparatus recorded (i.e., liquid level in stages, phase appearance in decanters, and foaming).

Objective: Determine the maximum hydraulic capacity of the contactor apparatus with optimized solvent..

Sampling and Analytical requirements: No samples of process streams or chemical analyses are required during the test.

\section{Test 2: Tank 37/44 Simulant with ${ }^{137}$ Cs Tracer Test}

Test description: This test uses the 33-stage 2-cm contactor apparatus with the optimized solvent and a ${ }^{137}$ Cs spiked Tank 37/44 simulant. All four process steps (extraction, scrub, strip, and wash) will be operated simultaneously in a 12-hour test. Organic and aqueous stream flows will be controlled and monitored by the computerized control and data acquisition system. Flow rates will be set near the maximum hydraulic capacity determined in Test \#1. The apparatus will be monitored for hydraulic stability. 
Objective 1: Measure decontamination and concentration factors in process streams.

Sampling and Analytical requirements: Three process streams (aqueous raffinate, strip effluent, and stripped solvent) will be sampled hourly during the test (12 samples for each stream, total 36 samples). These samples will be analyzed for ${ }^{137} \mathrm{Cs}$ by gamma scan. The spiked simulant solution will be sampled and analyzed for its major constituents and ${ }^{137} \mathrm{Cs}$.

Objective 2: Measure changes in solvent composition

Sampling and Analytical Requirements: The solvent hold tank will be sampled initially and at the end of the test ( 2 samples). These will be analyzed for modifier and BOBCalix (by HPLC), TOA TMA, n-butanol, and TBP (by GC-MS). Metals (Al, K, and others) will be analyzed by ICP-ES directly on the solvent samples.

Objective 3: Measure entrainment of solvent in the aqueous raffinate, strip raffinate, and spent wash solutions. Measure entrainment of the strip solution in the solvent.

Sampling and Analytical Requirements: Entrainment will be determined by measuring the volume of the separated phase that accumulates in the decanters. Entrainment that passes the decanters will not be measured.

\section{Test 3: Tank 37/44 Composite Waste Test}

Test description: This test uses the 33-stage 2-cm contactor apparatus with the optimized solvent and Tank 37/44 composite waste. All four process steps (extraction, scrub, strip, and wash) will be operated simultaneously in a 24-hour test. Organic and aqueous stream flows will be controlled and monitored by the computerized control and data acquisition system. Flow rates will be set near the maximum hydraulic capacity determined in Tests \#1 and \#2. The apparatus will be monitored for hydraulic stability.

Objective 1: Measure decontamination and concentration factors in process streams.

Sampling and Analytical requirements: Three process streams (aqueous raffinate, strip effluent, and stripped solvent) will be sampled hourly during the test ( 24 samples for each stream, total 72 samples). These samples will be analyzed for ${ }^{137} \mathrm{Cs}$ by gamma counting. The aqueous raffinate and stripped solvent samples will contain low levels of activity and will be removed from the cells for counting. The strip effluent will be highly radioactive and will be transferred to Cell Block B analysis using the in-cell counter.

Objective 2: Measure changes in solvent composition

Sampling and Analytical Requirements: The solvent hold tank will be sampled initially, and at the end of the test (2 samples). These will be analyzed for modifier and BOBCalix (by high performance liquid chromatography (HPLC)), TOA, TMA, n-butanol, and TBP (by gas chromatography-mass spectrometry (GC-MS)). Metals (Al, K, and others) will be analyzed by inductively coupled plasma-emission spectroscopy (ICP-ES) directly on the solvent samples.

Objective 3: Measure entrainment of solvent in the aqueous raffinate, strip raffinate, and spent wash solutions. Measure entrainment of the strip solution in the solvent. 
Sampling and Analytical Requirements: Entrainment will be determined principally by measuring the volume of the separated phase that accumulates in the decanters. In addition, organic entrainment (in the three aqueous streams) that escapes the decanters will be measured by analyzing samples for solvent components and sec-butylphenol. Duplicate samples of the three aqueous streams shall be taken in preweighed glass vials after 5 and 11 , and 17 hours (18 samples). The sample vials must be weighed with sample, extracted, and the extract analyzed. Modifier and BOBCalix are analyzed by HPLC. Isopar ${ }^{\circledR}$ L, TOA, and sec-butylphenol are analyzed by GC-MS (semi-volatile organic analysis (SVOA) procedure).

Objective 4: Measure stage efficiencies.

Sampling and Analytical Requirements: At the end of the test, all 33 stages will be drained and saved. Every other stage sample will be analyzed. The hottest phases will be separated in the Shielded Cells and the others may be removed and separated in a radiohood. Both phases will be sent for analysis of ${ }^{137} \mathrm{Cs}$ by gamma scan.

\section{Test 4: Tank 37H Dissolved Salt Simulant with Cs-137 Tracer Test}

Test description: This 4-hour test serves the same purpose and will be performed as described above for Test 2. The only exception will be the use of Tank $37 \mathrm{H}$ dissolved salt spiked simulant instead of Tank 37/44 simulant. The objectives and analytical requirements are identical to Test 2 .

\section{Test 5: Tank 37H Dissolved Salt Actual Waste Test}

Test description: This test serves the same purpose and will be performed as described above for Test 3. The only exception will be the use of Tank $37 \mathrm{H}$ dissolved salt actual waste instead of Tank 37/44 composite waste. The objectives and analytical requirements are identical to Test 3 .

\section{SIMULANT, SCRUB, STRIP, AND WASH SOLUTIONS}

The composition of the simulant, solvent, scrub, strip, and wash solutions must be verified before use. Physical properties (density, viscosity, and heat capacity/thermal conductivity) of the simulants, Tank 37/44 composite waste, Tank $37 \mathrm{H}$ dissolved salt waste, solvent, scrub, strip, and wash solutions are required. Table II lists the analytical requirements for these solutions.

\section{STAGE SAMPLE HANDLING}

Stage samples will be obtained from all stages at the end of each test. However, not all of the samples will be analyzed. Samples that are not analyzed initially will be saved as backups in case the initial samples are compromised. All stage samples will be taken in polypropylene bottles.

Stage samples will be shaken in the polypropylene bottles for approximately one minute and then transferred to separatory funnels. The solutions will be allowed to separate for a 
minimum of 16 hours, whereupon the two phases will be separated. The intermediate portions containing aqueous and solvent will be discarded.

\section{HIGHLY RADIOACTIVE SAMPLES}

During the radioactive waste tests (Tests 3 and 5), some samples will be too radioactive to remove from the Shielded Cells. The aqueous concentrate and some of the stage samples will contain ${ }^{137} \mathrm{Cs}$ in excess of $5 \times 10^{7} \mathrm{~d} / \mathrm{m} / \mathrm{mL}$ which prior experience has shown to be a practical limit for removal of a few milliliters of sample. Aqueous or organic samples requiring gamma scans will be transferred to Cell Block B and analyzed in the in-cell counter. For aqueous samples requiring organic analyses for carryover of solvent, the samples will be extracted in the cell and the extract removed for analysis. 
WSRC-TR-2002-00243, REV. 0

\section{TABLE A-I. Summary of Sampling and Analytical Plan}

\begin{tabular}{|c|c|c|c|c|c|c|}
\hline $\begin{array}{l}\text { Stream: } \\
\text { Origin }\end{array}$ & $\begin{array}{l}\text { Aqueous raffinate } \\
\text { decontaminated salt } \\
\text { solution (as it exits } \\
\text { extraction section) }\end{array}$ & $\begin{array}{l}\text { Strip effluent } \\
\text { concentrated } \\
\text { cesium product } \\
\text { as it exits } \\
\text { strip section }\end{array}$ & $\begin{array}{l}\text { Solvent recycle } \\
\text { solvent exiting } \\
\text { the strip section }\end{array}$ & $\begin{array}{l}\text { Solvent hold tk } \\
\text { solvent from the } \\
\text { collection/feed tk } \\
\text { as it is pumped } \\
\text { to the wash stage }\end{array}$ & $\begin{array}{l}\text { Solvent wash } \\
\text { spent wash sol'n } \\
\text { (from } \\
\text { accumulation tank) }\end{array}$ & $\begin{array}{l}\text { Stage } \\
\text { solvent and aqueous } \\
\text { (from each stage at } \\
\text { at end of test) }\end{array}$ \\
\hline
\end{tabular}

Test 1:Hydraulic Capacity Test with Simulant

no samples required except verification of simulant, scrub, strip, and wash solutions compositions (See Table II)

\begin{tabular}{|c|c|c|c|c|c|c|c|c|}
\hline $\begin{array}{l}\text { Sampling point: } \\
\text { interval }(\mathrm{h})\end{array}$ & $\begin{array}{c}S P-1 \\
1\end{array}$ & & $\begin{array}{c}\mathrm{SP}-3 \\
1\end{array}$ & & $\begin{array}{c}\mathrm{SP}-2 \\
1\end{array}$ & $\begin{array}{c}\text { SP-5 } \\
0 \text { \& final }\end{array}$ & SP-4 & \\
\hline Tot samples & 12 & & 12 & & 12 & 2 & & \\
\hline Samples to ADS & 12 & & 12 & & 12 & 2 & & \\
\hline $\begin{array}{l}\text { Requested } \\
\text { analyses }\end{array}$ & $\begin{array}{c}\text { Gamma } \\
\text { scan }\end{array}$ & & $\begin{array}{c}\text { Gamma } \\
\text { scan }\end{array}$ & & $\begin{array}{c}\text { Gamma } \\
\text { scan }\end{array}$ & $\begin{array}{l}\text { HPLC } \\
\text { SVOA } \\
\text { ICP-ES }\end{array}$ & & \\
\hline $\begin{array}{c}\text { Test 3: Tk } 37 / 44 \text { Composite } \\
\text { Sampling } \\
\text { interval (h) }\end{array}$ & $\begin{array}{c}\text { Naste Tes } \\
1\end{array}$ & $\begin{array}{l}\text { (24 hours) } \\
\text { at } 5,11,17 \mathrm{~h}\end{array}$ & 1 & at $5,11,17 \mathrm{~h}$ & 1 & $0 \& 24$ & at $5,11,17 \mathrm{~h}$ & 33 \\
\hline Tot samples & 24 & 3 & 24 & 3 & 24 & 2 & 3 & 66 \\
\hline $\begin{array}{l}\text { Samples to ADS } \\
\text { Requested } \\
\text { analyses }\end{array}$ & $\underset{\substack{\text { Scan } \\
\text { Gamma }}}{24}$ & $\begin{array}{l}3 \\
\text { HPLC } \\
\text { SVOA }\end{array}$ & $\begin{array}{c}24 \\
\text { Gamma scan } \\
\text { in B Block }\end{array}$ & $\begin{array}{l}3 \\
\text { HPLC } \\
\text { SVOA }\end{array}$ & $\underset{\substack{\text { Gamman } \\
\text { scan }}}{24}$ & $\begin{array}{c}2 \\
\text { HPLC } \\
\text { SVOA } \\
\text { ICP-ES }\end{array}$ & $\begin{array}{l}3 \\
\text { HPLC } \\
\text { SVOA }\end{array}$ & $\begin{array}{c}\text { 32 } \\
\text { Gamma } \\
\text { (on both } \\
\text { phases) } \\
\text { phases) }\end{array}$ \\
\hline
\end{tabular}

Test 4 :Tank $37 / 44$ Tracer Simulant Test (4 hours)

This test is identical to Test 2 but with a different simulant and shorter length.

Test 5: Tk 37H Dissolved Salt Waste Test (24 hours)

This test is identical to Test 3 but with a different waste solution.

$\begin{array}{lr}\text { Totals: } & \text { HPLC } \\ \text { ICP-ES } & 8 \\ \text { SVOA (GC-MS) } & 26 \\ \text { Gamma scan } & 256 \\ \text { Sum for ADS } & 316 \\ \text { \#of samples } & 282\end{array}$

Notes: HPLC measures BOBcalix, modifier

SVOA measures trimethylamine (TMA), trioctylamine (TOA), dioctylamine (DOA)

sec-butyl phenol(SBP), tributylphosphate(TBP)

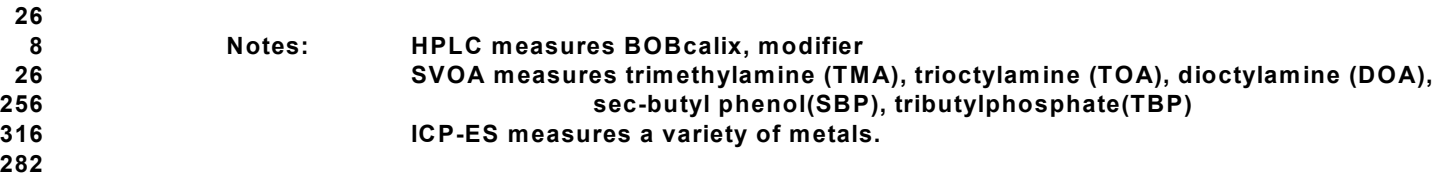


TABLE A-II. Analyses of Simulant, Scrub, Strip, and Wash Solutions.

$\underline{\text { Component }}$

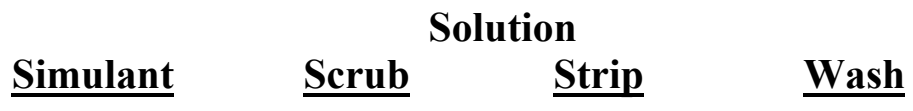

Total acid

$\mathrm{x}$

$\mathrm{x}$

Total $\mathrm{OH}$

$\mathrm{X}$

$\mathrm{X}$

Free $\mathrm{OH}$

$\mathrm{X}$

Carbonate

$\mathrm{X}$

Aluminate

IC anions

IC (DBP)*

$\mathrm{X}$

Cs (AA)

$\mathrm{K}$ (AA)

$\mathrm{Na}$ (ICP-ES)

SVOA**

${ }^{137} \mathrm{Cs}$ (gamma scan)

$\mathrm{x}$

$\mathrm{x}$

$\mathrm{X}$

$\mathrm{X}$

$\mathrm{x}$

$\mathrm{x}$ (triplicate)

*For dibutylphosphate.

** For trimethylamine and tributylphosphate. 